\title{
Crafting a More Appropriate Pentecostalism: Five Symbolic Boundaries
}

Great differences may arise between lower and middle class churches. The comparison conducted in the preceding chapter presented the cases of two Pentecostal churches that display significant discrepancies with regard to their social composition and religious style. The empirical comparison between these two churches highlighted potential boundaries between lower and middle class Pentecostalism. The comparison remains limited, however, insofar as it considers only two churches. Therefore, this chapter will broaden the perspective by taking into account a variety of Pentecostal churches in and around Buenos Aires city and the in-depth interviews which were conducted with middle class pastors and Pentecostals from different churches.

The central objective of this chapter is to explore the boundary work of middle class Pentecostals along with their religious taste and style. ${ }^{1}$ The religious taste and style described in this chapter are that of a middle class majority: a taste and style which are predominant among the middle class churches and interviewees of the sample. ${ }^{2}$ As will be shown, both the style and taste of the churches culminate in a tendency towards a more "appropriate" Pentecostalism that draws symbolic boundaries in opposition to other Pentecostals. Observing the boundary work of middle class Pentecostals, one can distinguish five types

1 The notion of religious taste refers to the religious preferences that devotees manifest, while the notion of religious style refers to the visible expressions of their religiosity. The exploration, analysis, and description of religious styles and tastes were originally carried out in two separate parts. However, during the analysis there turned out to be vast overlaps between the religious styles of middle class churches and the tastes of middle class devotees. In order not to render this study too redundant, both will be discussed together.

2 Middle class churches are considered to be churches in which the majority of members are from the middle class. The definition of social classes follows the technical definition given above. Thus, the majority of members in middle class churches will have completed a secondary school degree. They live in stable economic situations and have an income that is above average for the Argentinean population. Typical occupations among this group are qualified technical or service employees, professionals, teachers, small and medium-sized business owners, and free-lancers. Finding Pentecostal churches with a pronounced middle class membership is not an easy task in Argentina. There are, however, a few churches that include a high proportion of middle class individuals. I will call these churches "middle class churches".

(C) JENS KOEHRSEN, 2016 | DOI 10.1163/9789004310148_009

This is an open access chapter distributed under the terms of the Creative Commons Attribution-

Noncommercial 3.o Unported (CC-BY-NC 3.0) License. 
of boundaries: legitimate, structural and organizational, educational, expressive, and moral boundaries. The classification into these five types of boundaries is not based on clear cut distinctions. Empirically, boundaries often overlap and are combined. For instance, educational boundaries also become apparent as organizational boundaries in the form of educational facilities in middle class churches. Nevertheless, classification into these five boundaries allows for a rough differentiation between different types of boundaries that are drawn in opposition to other Pentecostals. Each of the five boundaries will be described in a specific section. Particular emphasis will be placed on expressive boundaries, since they lend themselves well to portraying the boundary work of middle class Pentecostals.

\subsection{Legitimacy and Power: "Legitimate" Boundaries}

The first boundary concerns the institutionalization and legitimacy of Pentecostal churches. During the field research it became evident that middle class churches are highly integrated into the formal institutions of evangelical Protestantism. These institutions were created in order to generate a common identity and to legitimize evangelical Protestantism. The most important among these are evangelical umbrella organizations, educational institutions, and evangelical newspapers. Middle class churches are not only highly integrated in these institutions; they even tend to control them. By creating a formal type of Pentecostalism, they draw boundaries of legitimacy in opposition to other Pentecostals.

Algranti proposes the notion of "formal circles of Pentecostalism" in order to distinguish between institutionalized, formal types of Pentecostalism and informal circles of non-institutionalized Pentecostalism. He applies the notion of formal circles of Pentecostalism to churches that are registered in the Registro Nacional de Culto (registro) and affiliated with ACIERA and/or FECEP. In opposition to the formal circles, the informal circles of Pentecostalism consist of churches that are neither registered in the registro nor affiliated with an official evangelical umbrella organization. ${ }^{3}$ This notion of formal circles is helpful to distinguish different degrees of institutionalization and legitimacy among Pentecostals.

I adopt this concept, but instead of "formal circles", I use it to refer to a single "formal circle" and add more elements to it. While the registro and the enrolment in ACIERA and/or FECEP are basic requirements for entering the formal

3 See Algranti 2010: 84-85. 
circle, participation in the Consejo de Pastores (consejo), the educational training of pastors, and their activity in a Bible institute and/or an evangelical newspaper form additional features that attribute formal recognition and legitimacy to a church. The greater number of these conditions a church meets, the deeper its integration in the formal circle and the higher its degree of formal recognition and legitimacy. Thus, features like enrolment in ACIERA and/or FECEP, participation in the consejo, educational training of pastors, and potentially the activity of pastors in a Bible institute and/or an evangelical newspaper define the degree of institutionalization and legitimacy of a church from the viewpoint of the formal circle. Churches that do not meet these requirements are instead not integrated into the formal circle and have a rather low degree of formal recognition. They are - willingly or unwillingly - excluded from the formal circle. Examples are churches such as IURD, God Is Love, Cumbre Mundial de Los Milagros, and many small and medium-sized churches situated in lower class neighborhoods in the surroundings of Buenos Aires. These churches are neither affiliated with ACIERA and FECEP, nor do their pastors participate in the consejo. Their pastors usually have not received theological training from one of the recognized institutions nor do they participate in evangelical newspapers such as El Puente. Moreover, countless smaller churches located in poor neighborhoods and slums are not even registered in the registro. Instead of participating in formal Pentecostalism, they constitute a Pentecostal "black market": from the viewpoint of formal Pentecostalism these churches are barely legitimate. ${ }^{4}$ Hence, the unifying effect of evangelical institutions functions at the same time as a mechanism of exclusion. The formal circle with its institutions does not represent the whole movement, but only a fraction of it.

The following paragraphs tackle the particular relationship that middle class churches have with the formal circle. This relationship is characterized by an intimate proximity - if not an almost complete overlap with the formal circle - since middle class churches are highly engaged in the formal circle.

The middle class churches that I studied in Buenos Aires are involved in the official umbrella organizations of evangelical Protestantism. They are affiliated

4 Knoblauch (2007) also uses the term "black markets of religion". He applies the term, however, for non-organized or fluid forms of religion which are not religious in the narrow sense of the term. Thus, the term as applied in Knoblauch's approach refers rather to modern, noninstitutionalized and partly individualized - or in Luckmann's (2000/1960) terminology, "invisible" - forms of religion. I use the term "black market of religion", instead, in order to distinguish between organized religious actors that assume a type of legitimacy and those that are regarded as less legitimate or illegitimate. 
with at least one of the umbrella organizations, many of them even with both - ACIERA and FECEP. ${ }^{5}$ Moreover, pastors from middle class churches are enrolled in the Consejo de Pastores de la ciudad de Buenos Aires. ${ }^{6}$ Interestingly, in addition to the formal networks there exists in these bodies a more exclusive network of close personal bonds between middle class pastors. Middle class pastors in the city of Buenos Aires reported to me that they maintained close friendships with each other. They stay in close contact, meet on a regular basis, and invite each other to preach in their churches.

ACIERA, FECEP, and the consejo $(s)$ represent the core institutions of the formal circle. Middle class pastors are not only actively engaged in these organizations, they also tend to control them by assuming leadership positions in these organizations. The majority of chairs and official positions in these organizations are usually held by pastors of middle class congregations. Therefore, middle class Pentecostalism controls the core institutions of the formal circle.

Another factor contributing to the formal recognition of a church is its relationship to the registro. Middle class churches not only keep to the legal standards and are enrolled in the registro, but some of them such as $A C$ and Iglesia del Libertador even received official acknowledgements from this secular body which they exhibit in their entrance halls.

While middle class churches are enrolled in the registro and participate in the umbrella organizations of evangelical Protestantism, many - if not most non-middle class Pentecostal churches are neither inscribed in the registro nor enrolled in ACIERA or FECEP and do not participate in an organization like the consejo. ${ }^{7}$ This does not mean that these churches are intentionally excluded from these bodies. Nevertheless, affiliation with these organizations is not as simple as it may seem since a church that wants to enroll (1) has to know and

5 Moreover, many middle class churches form part of one of the traditional Pentecostal bodies in Argentina such as the Asamblea de Dios, Unión de las Asambleas de Dios, Asamblea Cristiana or the Asociación de la Iglesia de Dios.

6 The Consejo de Pastores de la ciudad de Buenos Aires is a network for pastors from the city of Buenos Aires. The pastors who form part of the consejo meet on a regular basis to discuss organizational topics and strategies. Pastors from churches located outside the city of Buenos Aires can participate in other consejos. Theoretically, there are consejos in each part of the province of Buenos Aires.

7 Pastor Pedro explains the absence of lower class pastors and churches in these organizations by the fact that these umbrella organizations are strongly shaped by the middle class (Interview Pastor Pedro Part 2). The degree of enrollment varies among non-middle class Pentecostal churches. Churches like IURD, GIL and Cumbre Mundial de los Milagros, for instance, are enrolled in the registro, but are not accepted as members in ACIERA, FECEP or the Consejo de Pastores de la ciudad de Buenos Aires. 
care about the affiliation, (2) needs the bureaucratic skills and knowledge to manage the enrollment procedure, and (3) often needs a contact from a church already enrolled in these organizations. ${ }^{8}$ Pastor Pedro supposes that most of the smaller churches in the conurbano do not even know that umbrella organizations like ACIERA and FECEP exist. ${ }^{9}$ Small churches outside the city of Buenos Aires - which represent the majority of Pentecostals congregations generally go without any public voice or representation. ${ }^{10}$ They remain in the shadows of the lower class neighborhoods and slums of the conurbano without enjoying any type of formal recognition and visibility, while urban middle class Pentecostals endeavor to represent Pentecostalism through their umbrella organizations.

Churches that are not enrolled in one of the umbrella organizations may be regarded as dubious." ${ }^{11}$ Thus, some of the middle class interviewees tackle the topic of legitimacy and argue that churches should be affiliated with an umbrella organization. They suppose that a church needs a legal frame legitimizing its existence and its form of practice. Eduardo, for instance, explains that affiliation in an umbrella organization would facilitate the supervision and collective control of churches. ${ }^{12}$ Another example is Claudia, who states that there should be legal head organizations in place in order to control congregations. According to her, the lack of such control is a serious flaw of many smaller lower class churches. Watching a video of a smaller church located in the conurbano of Buenos Aires, she states that many smaller churches in poorer places do whatever they want since they lack a central control which could regulate their activity. ${ }^{13}$

$8 \quad$ Interview Pastor Oscar Part 2.

9 Interview Pastor Pedro Part 2.

10 There is an umbrella organization which tries to represent smaller Pentecostal churches: FIPA (Federación de Iglesias Pentecostales Argentina). Yet, this umbrella organization enjoys less power and recognition than ACIERA and FECEP and integrates only a small fraction of the existing smaller churches.

11 Pastor Pedro describes inter-congregational exchange and accountability as functions of these umbrella organizations (Interview Pastor Pedro Part 3).

12 See Interview Eduardo.

13 Interview Claudia Part 2. Nevertheless, the degree to which evangelical umbrella organizations are able to exercise such control is questionable. Although umbrella organizations may contribute to the accountability of Pentecostal churches, it seems rather to be the belief that these organizations contribute to the accountability of the churches enrolled that increases their credibility and legitimacy. Since umbrella organizations integrate numerous churches they are not able to maintain a strong relationship with each of them. 
Another important institution that characterizes the formal circle and contributes to the legitimacy of Pentecostal churches is education. Various Bible institutes have been opened to provide religious education and to formalize the training of pastors. Remarkably, pastors of middle class congregations not only hold some type of theological degree, but also maintain strong relationships with these educational facilities. Many of them work or have worked as teachers in one of the Bible institutes. Moreover, some of these educational facilities were founded by middle class pastors ${ }^{14}$ and are still run by them. Positions as teachers or directors in Bible institutes are prestigious among Pentecostals and confer an outstanding status to a pastor. Being a teacher or even a director of one of the Bible institutes contributes to the recognition of the pastor and his congregation. Thus, congregations are often evaluated according to the educational background of their leadership. Churches led by pastors with a low educational background are seen critically by middle class Pentecostals. Pastor Oscar from the middle class church Iglesia del Libertador regards the lack of education as a central problem of many churches in the province of Buenos Aires:

(...) we know of pastors who do a terrible job, because they don't have any real Biblical training. They have opened new churches because of some disagreement they had with others, and without having any resources, they start to do things...they start with liberations (...) but with a total lack of knowledge. But we aren't really in contact; we don't have contact with those churches. We just hear about the things that happen. INTERVIEW PASTOR OSCAR PART 2

Pastor Oscar not only criticizes the supposed lack of education but also points out that his congregation does not want any kind of contact with these churches. The absence of a substantial educational training is disapproved of and has a negative impact on the recognition of a church. ${ }^{15}$ The importance of education among middle class Pentecostals will be discussed in more detail

Moreover, it is not their principle aim to control churches but rather to give evangelical Protestantism and Pentecostalism a public voice. Pastor Pedro describes the principal objective of these organizations rather as a political one. See Interview Pastor Pedro Part 2.

14 For instance, FIET (Faculdad Internacional de Educación Teológica) was founded by Pastor Saracco who is head of a middle class congregation.

15 Also Pastor David describes the lack of training as the fundamental problem of Pentecostalism (Interview Pastor David). 
below. Here it is just important to remark that the educational status of a pastor may contribute positively or negatively to the legitimacy of his congregation.

Finally, two other factors that may further contribute to the legitimacy of churches are close contact with the evangelical print media and involvement in social projects. Many middle class pastors maintain good relationships with the national evangelical newspapers - El Puente and La Corriente - and write articles from time to time in these releases. ${ }^{16}$ Moreover, middle class congregations launch social aid projects and some of them have even received official distinctions for their social engagement. ${ }^{17}$

Different institutions contribute to the legitimacy of Pentecostal churches. These institutions, such as membership in an umbrella organization, allow for the drawing of "legitimate" boundaries, for distinguishing between "legitimate" and "less legitimate" or "illegitimate" Pentecostal churches. This institutionalization creates what Algranti calls a "formal circle of Pentecostalism", ${ }^{18}$ a group of institutionalized churches that establish themselves as legitimate religious actors in opposition to churches that do not participate in these institutions. Middle class Pentecostals are not only strongly involved in these institutions, the institutions related to the formal circle are even run by middle class pastors. Thus, middle class Pentecostals shape the policy of the institutions that formally represent Pentecostalism in Argentina. Their position allows them to accumulate power and to control access to the institutions that legitimatize churches. By controlling access to the formal circle they can enforce definitions of "appropriate" and "legitimate" Pentecostalism. The fact that ACIERA and FECEP rejected the IURD's application and withdrew Ondas de Paz y Amor from its registers illustrates their power to define "legitimate" Pentecostalism. ${ }^{19}$

16 Pastor Pedro describes El Puente as a typical publication for middle class Pentecostals (Interview Pastor Pedro Part 2).

17 Pastor Pedro states that his ex-congregation Iglesia del Centro twice received distinctions from the Peruvian government for being the non-governmental institution that most assisted Peruvian citizens in Argentina. See Interview Pastor Pedro Part 2. For further information regarding the social engagement of middle class churches, see subsection 8.5.3.

18 See Algranti 2010: $84-85$.

19 For the exclusion of the IURD from the circle of Pentecostal churches, see also Semán 2003: 69-71. Interestingly, also sociologists of religion may get involved in drawing boundaries. Thus, famous scholar of Argentinean Pentecostalism Wynarczyk refuses to define the IURD as Pentecostal or even evangelical. Instead, he describes the IURD as "parapentecostal" and excludes the church from a detailed consideration in his work. See, for instance, Wynarczyk 2003: 35; 2009a: 53 . 
One of the institutions' objectives related to the formal circle is to improve the legitimacy and position of Pentecostalism in the religious field and in society. Aspiring for legitimacy, the formal circle seeks to monopolize the definition of Pentecostalism and to (re)define Pentecostalism as a socially acceptable and legitimate religion. Churches with a questionable reputation have to be excluded from what is publicly defined by the formal circle as Pentecostalism, since their presence imperilsthe creation of a socially acceptable Pentecostalism and the accumulation of legitimacy.

The rejection of churches from the formal circle implies that they do not represent acceptable forms of Pentecostalism. Nevertheless, rejection by the formal circle does not prevent these organizations from attracting large numbers of believers. The success of "illegitimate" Pentecostal churches such as the IURD shows that the definitions of appropriateness and legitimacy imposed by the formal circle do not concern the entire Pentecostal community. Instead, they appear to concern mainly a specific circle of Pentecostals: particularly middle class Pentecostals and those who are actively or passively integrated in the formal circle. Hence, the criteria for legitimacy imposed by the formal circle constitute a partial view that is particularly promoted by middle class Pentecostals. The majority of Pentecostals who are affiliated with small churches outside the city of Buenos Aires do not seem to care about the formal recognition of their church by these institutions.

Based on these observations one can outline a rough model of the field of Pentecostalism. ${ }^{20}$ The Pentecostal field is organized on the basis of two types of resources: (1) the legitimacy of churches according to the formal circle of Pentecostalism, and (2) the public impact of the church, defined here by its public visibility among Pentecostals and its size. Using these two criteria, one can sketch a field model with two scales: the vertical scale shows the legitimacy as defined by the formal circle and the horizontal scale exhibits the impact of a church defined by its size and public visibility.

Figure 17 shows a rough sketch of the field of Pentecostalism in Argentina. This sketch serves only as a general illustration of the ideas presented here. The legitimacy of religious actors is defined by the standards of the formal circle. Only churches which fulfill the requirements of the formal circle are considered to be legitimate religious organizations. These churches are located in the upper area of the field. By contrast, churches which do not participate in the

20 The concept of the religious field is based on Seibert's approach to the religious field. However, in contrast to the field which is proposed here, he defines the field around two different types of resources: organizational complexity and credibility (Seibert 2010). 


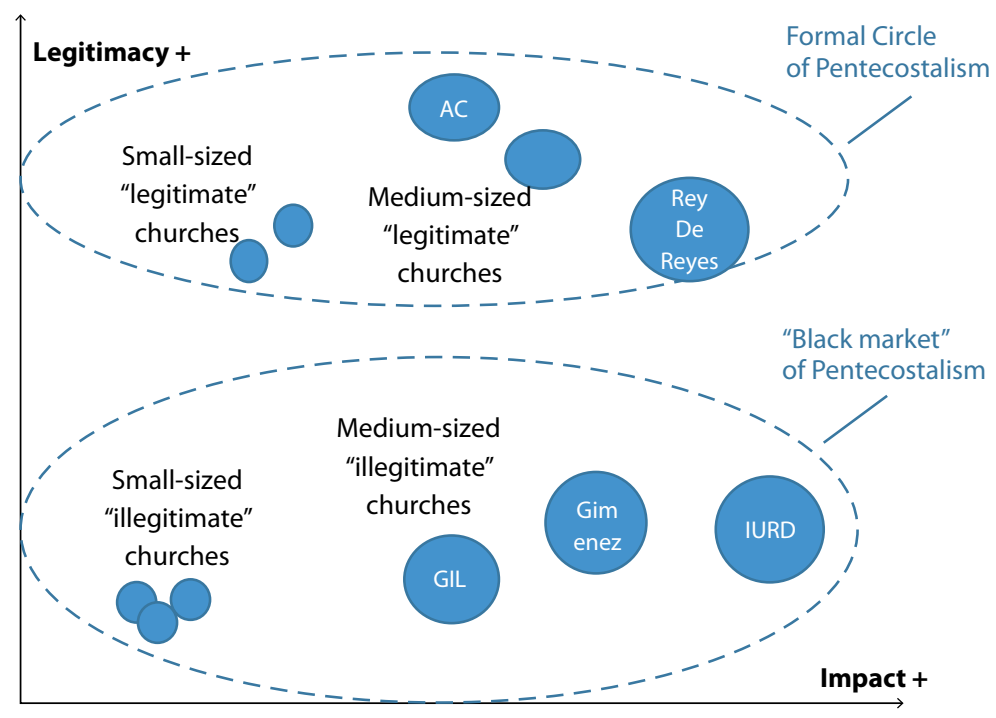

FIGURE 17 The field of Pentecostalism in Buenos Aires ${ }^{21}$

institutions of the formal circle are regarded as less legitimate and are therefore located at the lower end of the field. The churches with the highest impact in terms of public visibility and size are situated at the far right while smaller churches with little public visibility are located at the far left.

The middle class churches that I studied are located together with AC in the upper middle and left areas of the field. They are medium-sized or small churches which are highly integrated in the formal circle of Pentecostalism.

From the perspective of the formal circle of Pentecostalism, the lower part of this figure forms a "black market" of Pentecostalism: churches located here are not recognized by an umbrella organization and their pastors lack theological training. Therefore, they are perceived as illegitimate - or at least less legitimate - religious organizations. The "black-market of Pentecostalism" is dominated by a high variety of Pentecostal churches: the vast majority of smaller churches in the conurbano and slums of Buenos Aires are likely to form part of this "black market", but also many medium-sized and even some larger churches like the IURD offer their religious products on the "Pentecostal black market". Nevertheless, most religious "consumers" appear not to care about the legitimacy of the religious goods they consume. The "black market" of Pentecostalism will include considerably more churches and followers than the

21 Source: own. 
formal, "official market". Thus, in numerical terms, informal Pentecostalism rather than formal Pentecostalism represents the whole of Pentecostalism, whereas in terms of symbolic power general Pentecostalism is represented by the formal circle which is highly shaped by middle class Pentecostalism.

The field of Pentecostalism represents only a partial view. As already stated, not all Pentecostals seem to care about the legitimacy criteria established by the formal circle. Particularly middle class Pentecostals appear to enforce these criteria. For other Pentecostals, other legitimacy criteria may be important. A criterion that may turn out to be especially important among lower class Pentecostals, for instance, is the effectiveness of the Holy Spirit in a congregation. Congregations which are believed to experience a high presence of the Holy Spirit enjoy a high popularity. Hence, it is questionable whether the field sketched out here represents legitimacy standards that are shared by the whole or the majority of Pentecostals. The legitimacy standards discussed here are formal standards that are particularly present among middle class Pentecostals. By promoting formal legitimacy standards they seek to establish their churches as legitimate religious organizations. They create "legitimate" boundaries in opposition to other Pentecostal churches.

\subsection{Excellence and Order: Structural and Organizational Boundaries}

Excellence and order are important values for middle class Pentecostals. Middle class interviewees and churches portray themselves as committed to these values. Churches and their members are expected to give their best in order to provide a high quality of religious and secular services. Their affinity for quality goes along with their preference for tidiness and order. Stressing these values, middle class Pentecostals draw boundaries in opposition to Pentecostal churches which are located in "untidy" places and in which order and quality appear to play a minor role. Particularly the small churches in the conurbano and villas are experienced as untidy and poorly organized. Moreover, they are located in unsafe places that the middle class tends to avoid. ${ }^{22}$

22 The degree of organization and infrastructure often goes hand in hand with the size of a church. Thus, many larger and mega churches develop a massive organizational structure while smaller churches lack the resources to build up a vast organizational structure. Yet, not only church size determines the organization and infrastructure of a church. Although many larger and medium-sized churches possess a poor infrastructure and organization, most of the medium-sized middle class churches have developed a substantial organization and infrastructure. Two examples of large churches with poorer infrastructure, for 
The appreciation of excellence and order becomes particularly manifest in the infrastructure, the church organization and the structure of church services. Being committed to excellence and order, middle class Pentecostals draw organizational and structural boundaries. They engage in creating distinctions from the organizational and structural features of other Pentecostal churches.

\subsubsection{Safe and Tidy Locations}

The most evident structural boundary refers to the location and infrastructure of middle class churches. Middle class churches are located in specific places. They are not located where one finds the majority of Pentecostal churches, in the poor suburbs and slums of Buenos Aires, but in middle class neighborhoods. There is a geographical segregation of middle class churches: churches with a significant proportion of middle class members are usually situated in the urban, middle class districts of Buenos Aires. In poorer districts within and outside Buenos Aires, on the contrary, churches attract almost exclusively the lower class. These churches recruit their members basically from the surrounding neighborhood and therefore from the lower class. As described above, the density of Pentecostal churches is significantly higher in these neighborhoods than in the middle class districts of Buenos Aires city. Most Pentecostal churches are located in lower class neighborhoods of the conurbano. ${ }^{23}$ By contrast, churches in the middle class neighborhoods of Buenos Aires city represent only a fraction of the movement. Middle class Pentecostals preferably frequent churches in these middle class neighborhoods. Consequently, churches which are predominantly middle class or mixed are limited to middle class districts. ${ }^{24}$ The distribution of middle class churches has one simple reason:

instance, are Manantial de Bendiciones and Cumbre Mundial de los Milagros. Both are lower class churches and attract a comparatively high number of participants to its weekly church services.

23 See Semán 2006a: 199-202.

24 In middle class districts, one can find not only middle but also lower class churches and larger churches with a highly mixed social composition. Many of the medium-sized and larger churches in the urban middle class neighborhoods of Buenos Aires attract members from different districts in and around the city of Buenos. This is particularly the case for the well-known churches with famous preachers such as Rey de Reyes or Catedral de la Fe. Due to the high popularity and strong reputation which these churches enjoy, they attract individuals who live farther away and have to travel several hours in order to reach church services. Some of the middle class and lower class churches from our sample which are mainly located in Buenos Aires city - also attract their members from different parts in and around the city of Buenos Aires. Often members travel more than an hour to 
middle class Pentecostals are unlikely to affiliate with Pentecostal churches that are located in lower class neighborhoods due to safety and cultural concerns. Many middle class Porteños avoid entering lower class neighborhoods and in particular slums since these places are experienced as insecure and dangerous. ${ }^{25}$ Interestingly, geographical boundaries also become important for drawing other boundaries. When describing characteristics of Pentecostalism they perceive as negative, middle class Pentecostals usually refer to churches in the conurbano, in the poor suburban neighborhoods of Buenos Aires. They seek to distinguish themselves in particular from a type of Pentecostalism they believe to be prevalent in the poor conurbano.

A second structural characteristic concerns the infrastructure of churches. The physical infrastructure of middle class churches displays some general characteristics that many other Pentecostal churches do not share. Most of the middle class churches that I studied in Buenos Aires occupy physical locations which were originally constructed as churches. Their buildings include different facilities. Besides the basic facilities such as restrooms, entrance hall, and the main hall middle class churches have different halls for courses, groups and other activities, offices for pastors and secretaries, and a bookstore in the entrance hall. In general, the facilities are very well administered. There is no paint peeling from the ceiling or mold and water spots on the walls. Restrooms are clean and equipped with paper towels and soap. The main hall is equipped with sophisticated music and sound equipment and a projector that displays the song text and Bible readings on the wall. Walls are painted and floors are tiled. Heaters, ventilators, or air conditioning make the facilities of the church more comfortable.

The facilities of churches that one can find in lower class neighborhoods and slums in and around Buenos Aires are usually very different from those of middle class churches. Many of the locations were never constructed as

get to their church. However, living a bit farther from the church is less stressful for the middle class since they have access to cars. Many lower class Pentecostals living in the province of Buenos Aires instead have to take long bus trips in order to attend church services in the city of Buenos Aires.

25 A pastor of a church situated in a slum, for instance, mentioned to me that his church was planning to open a branch in a middle class neighborhood close to the existing branch in order to attract the middle class. According to him, the only possibility to attract the middle class was to open another branch in a middle class district since middle class individuals would refuse to enter slums they experienced as less secure. Slums are often perceived as a hotbed of crime and drug-business (Gorelik and Silvestri 2010; Guano 2004; Kessler 2010b). 
churches and consist of a sparsely decorated hall in which plastic chairs are assembled. Here, floors are not tiled and are just bare concrete. Paint may peel from the walls. Sometimes there are no heaters while the walls and doors have holes through which the wind may enter in the winter. In many smaller churches, the music and sound equipment is limited to a keyboard, speakers, and a guitar or drums. These churches are regularly much less comfortable than middle class churches.

Surprisingly, references to the infrastructure of churches are not as ubiquitous among middle class interviewees as one may suppose. In many cases middle class interviewees simply appear to take a good infrastructure and organization as givens, since most of them are members of well-equipped churches and have not directly experienced churches with poor infrastructure and organization. Nevertheless, there are several interviewees who display preferences concerning the infrastructure and organization. These interviewees prefer churches with a developed, comfortable, and orderly infrastructure. ${ }^{26}$ They do not necessarily want a luxurious infrastructure, but they reject the precarious infrastructure that one can find in many smaller churches in slums and lower class neighborhoods.

\subsubsection{Order and Organization}

Talking to members and pastors of middle class churches, the term "excellence" often appeared. The term was used particularly with respect to quality, tidiness, and order. Churches and their members are expected to give their best in order to provide a high quality of religious and secular services. This becomes visible not only with respect to the infrastructure but also to the organization of the church and the structure of church services and its music. The middle class churches that I studied have developed a sophisticated organizational structure in order to satisfy the requests and interests of their middle class members. In these churches, several pastors are dedicated to the spiritual wellbeing of church members while at least one secretary coordinates and assists their daily tasks. Moreover, these congregations generally offer an internet page, a ministry that carries out social projects, and a variety of groups, courses, workshops and other activities (e.g. weekend camps, soccer tournaments).

In analogy to these characteristics, middle class interviewees state that they prefer a church organization with a variety of ministries, activities and social

26 Javier, for instance, states that he likes the well administered interior of AC (Interview Javier). Mateo describes the space of the church Ministerio Apostólico Jesús Varón Guerra Y Libertad as a space where he would get depressed due to the poor infrastructure (Interview Mateo). 
projects. Particularly courses and workshops that contribute to members' education are welcomed. Some of the middle class interviewees stated that they like to have small groups in their church in which they are able to discuss their problems and pray in a more intimate context. These church groups are a general characteristic of middle class churches. ${ }^{27}$ There are usually two types of groups: specific groups, such as self-help groups for married couples, and regular groups, often called discipulados or celulas. The regular groups generally consist of 3 to 12 members. Meetings take place in the church or a member's home. These meetings provide a more intimate context in which church members can not only deepen their knowledge of the Bible but also discuss their problems and seek advice and support.

However, the most essential congregational practice remains the church service. Remarkably, middle class church services tend to be shorter than in other Pentecostal churches. Church services last between one and a half and two and a half hours in the middle class churches that I studied, while in many other Pentecostal congregations church services last from two and a half to as much as six hours. Middle class church services normally follow a common structure. They start with musical praise during which the participants arrive and are welcomed at the entrance by a pastor and/or ushers who may hand them the church program. The music is followed by a prayer, some organizational announcements, tithing and offering, and the sermon which takes up most of the time of the church service. The church service ends with a prayer and some short announcements regarding upcoming church events. In many other Pentecostal churches, the structure of services is less evident and appears to depend more on the intuition of pastors and members. ${ }^{28}$

Attributes that appear again and again in the interviews when it comes to the organization and practices of the church are "order" and "disorder/chaos". Often when practices in the videos were perceived negatively, they were described as chaotic. Thus, "disorder/chaos" has a clearly negative connotation whereas "order" is experienced as positive. Order refers to what middle class interviewees describe as a clear and comprehensible structure: every element

27 Church groups also exist in many of the larger churches while they tend to be less prevalent in medium-sized lower class churches. However, in lower class churches of medium and smaller size they are less prevalent.

28 Most of the lower class churches have their main service in the evening, while middle class churches tend to prefer Sunday morning for their main church service. Lower class churches frequently have difficulties attracting members to church services in the morning, since lower class Pentecostals prefer evening services. An exception among middle class churches is La Puerta Abierta where the main service takes place in the evening. 
occupies the position assigned to it due to a rational principle of organization. Order is experienced by the respondents, for instance, in good church administration, a clear assignment of responsibilities, and adherence to the official church schedules. ${ }^{29}$ In the context of the church service, "order" means that the actions of individuals (pastors, musicians, ushers, audience etc.) correspond to an organized and coordinated structure. "Chaos", by contrast, is associated with a lack of organization: participants do what they want without a visible social coordination.

Hence, middle class interviewees prefer well-structured and organized church services. Activities such as singing, praying, and preaching are expected to be arranged in a serial, planned order in which they follow one another in time. A mixing of activities or different individuals involved in different activities simultaneously is experienced as chaotic. Interviewees pointed out that this type of chaos is somehow typical for many Pentecostal churches. According to them, church services should also have a clear assignment of tasks: the responsibilities for each task - music, preaching, praying, doormen, etc. should be clearly assigned to specific members to avoid chaos. This concept of order also includes schedules. For some of the informants punctuality played an important role. According to these interviewees, church services should begin and end punctually and should not run on too long.

This sense of order is illustrated by Ana who dislikes a video of GIL. In this video participants of a GIL church service are simultaneously performing various activities such as singing, speaking to the pastor, blessing members, and praying. She describes what she sees as chaotic: every participant is doing something different. "Chaos" appears here as a lack of collective coordination. ${ }^{30}$ Also Emilia argues that participants should always focus collectively on one activity at a time and then together begin the next activity. After watching a video from GIL she says:

Emilia: I don't like the chaos. I don't like the music.

Interviewer: The chaos?

Emilia: The chaos. When people start walking around while other are praying.

29 Claudia mentions, for instance, that due to a bad delegation of tasks there were no possibilities for growth in her old church. The pastor tried to accomplish all tasks but did not manage to conduct a sufficient Bible teaching (Interview Claudia Part 1). She refers to the concept of order by stressing in particular the delegation of tasks in the church service (Interview Claudia Part 1).

$30 \quad$ Interview Ana Part 1. 
Interviewer: Why don't you like it?

Emilia: Because, either they are walking around or they are praying. I don't really know what they are doing. (...) I like it when we are singing or worshiping God, because we are more concentrated. Then we can go on to do something else. But I don't like it when the two things get mixed up. You see, that is another thing about Pentecostal churches that we don't like. I mean, neither my husband nor my children like it; we agree on that. If you go to the church to hear a message, you just want to hear the message. You don't want others to be speaking to the right, then to the left. Or for them to open a door, close a door, come in, go out, pim pum pam (...).

INTERVIEW EMILIA

Middle class interviewees show a taste for order that conveys social coordination and promotes the idea that every practice has its properly assigned place and time. According to this taste, Pentecostals should not follow their spontaneous impulses during church services but rather orient themselves to the collective structure of the church service which assigns a place to every type of activity and expression. This preference for a well ordered and controlled practice of Pentecostalism also concerns expressivity during church services, a topic that will be addressed below.

The ideal of order also appears in reference to the sermon. According to middle class interviewees, sermons should be well structured and convey a clear message. ${ }^{31}$ Eduardo is an example for this taste a structured style of preaching. He is a member of the mixed congregation Buenas Nuevas that offers each Sunday morning a church service more inclined towards the middle class and Sunday evenings a church service more inclined towards the lower class. He better prefers the style of the pastor who conducts the morning church service, Pastor Norberto, since he regards this pastor's style as much more structured than that of Pastor Moncho, the evening pastor:

Eduardo: I personally like Norbeto's preaching and preparation, (...) more than Moncho's.

Interviewer: What is the difference?

Eduardo: Moncho doesn't have official training. He doesn't have a degree in theology. He preaches more in an inspirational way. Norberto is more of a teacher of the Word. (...) I don't know if you studied theology, but when you put a sermon together, there is a technique, an order to it: an introduction....Moncho is more...his sermons don't have any order, and if 
you aren't used to listening to him you get lost in what he is trying to say. Norberto is more organized; you have an introduction, a body, and a conclusion. It's a different style.

INTERVIEW EDUARDO

Education is perceived by Eduardo as an element that facilitates an ordered sermon. Astonishingly, education is a subject that comes up with regard to almost every area of the church. For this reason, educational boundaries will be discussed in more detail in a separate section.

\subsubsection{Aspiring to Excellence in Music}

Middle class Pentecostals aspire to excellence. They do not want to practice their faith in a church that is mediocre. Churches are expected to strive for a high quality of religious practice. The demand for quality becomes particularly apparent with regard to the worship music.

The style and quality of music can differ significantly between Pentecostal churches. The middle class churches that I visited favor a quieter style of music consisting mainly of pop ballads and hymns. The musical style is overwhelmingly inspired by the Anglo-Saxon style of Christian pop music. Congregations tend to play songs from famous Christian composers and bands such as Marcus Witt, Hillsong, or Jesús Adrián Romero. Besides Christian pop music, hymns are a typical type of musical praise in middle class church services. Often songs form a mix of more classical hymns and pop music. In some churches bands also sometimes play jazz or classical music. ${ }^{32}$ Songs generally praise the goodness of God, his unconditional love and the presence of Jesus, and announce one's love and adoration for God. Bands consist of trained musicians and include at least a piano, electro bass, guitar, drums, a singer, and three or four background singers. Very typical are also a saxophone player, a chorus of between seven and twelve singers, and sometimes other wind and string instruments.

32 With regard to classical music, the opinions of middle class Pentecostals are divided. In some cases middle class Pentecostals are big fans of classical music and would like to listen mainly to classical music and hymns in their church services. This group forms a minority. The majority of middle class interviewees regard classical music as a good feature which should, however, not dominate the music during the church service. They welcom one or two pieces of classical music in the church service, while prefering pop music for the rest of musical contributions to the church service. Finally, another group of interviewees was against playing classical music in church services. They perceive classic music rather as a type of music for older people and prefer instead music that is more motivational. 
Middle class congregations make use of sophisticated sound and music equipment and a sound engineer at the rear end of the church hall. Song texts are generally projected on a wall behind or beside the pulpit.

In many Pentecostal churches, especially those of the poorer suburbs of Buenos Aires, the equipment of the church band is significantly poorer and bands include fewer musicians and instruments. Sometimes they only have a simple stereo equipment and a keyboard, other times they have drums and a guitar along with the keyboard. The keyboard is the most prevalent instrument in these churches, such that even in bigger bands the keyboard playing LatinAmerican rhythms usually assumes the central role for the musical praise. Not only is the equipment poorer, but also the musicians tend to be less trained than in middle class churches. Consequently, the quality and style of music can differ significantly from that of middle class churches.

Middle class interviewees prefer churches that provide an excellent quality of music and dislike what they call a bad quality of music. Therefore, church musicians are expected to be skilled and well trained and to play harmonically without making mistakes. In order to have a professional quality, the equipment is also important. Thus, some interviewees argue that churches should be well equipped with sound systems and instruments. ${ }^{33}$ Middle class interviewees also exhibit specific preferences concerning the type of music. Cumbia is not perceived as a type of music which enables devotees to be excellent. By contrast, middle class Pentecostals often experience it as a part of lower class culture which they reject. Hence, cumbia is regarded as a type of music that may be appropriate for lower class Pentecostals, but not for themselves. Instead, they prefer Christian pop music. Particularly Hillsong, Marcos Witt, and Jesús Adrián Romero have an appeal to middle class Pentecostals. Their music is described as harmonic and poetic. Miguel, for instance, argues after listening to a piece of music at GIL that this congregation has a poor quality of music. He likes the musical style of Hillsong and hates it when church musicians play disafinado, out of tune. ${ }^{34}$ Carlos is also a fan of Hillsong, which he names as an example of excellent Christian music:

(...) Hillsong for example. That is what captures the middle class - verses that are coordinated and thought out, with some element of poetry, and music that is much more thoughtful than "tachin, tapum, tachin tapum". That is what most appeals to the middle classes.

INTERVIEW CARLOS

33 See, for instance, Interview Emilia; Interview Eduardo.

34 Interview Miguel Part 2. 
Christian pop music is not only seen as a more ordered ("coordinado") and harmonic style of music than the "tachin, tapum" of cumbia but also as more thoughtful ("pensado"). Moreover, Carlos considers this type of music as matching with the middle class.

In sum, middle class Pentecostals are not only located in other types of neighborhoods than the majority of Pentecostal churches, they also establish boundaries with regard to their organizational structure and infrastructure. They develop highly equipped and well administered facilities, offer a variety of activities and courses, a high quality of music and well-structured church services, as opposed to other Pentecostal churches that are often conceived of as poorly organized, unstructured, and lacking in quality. Structural and organizational boundaries are perhaps the most evident boundaries since they become visible in the infrastructure and organization of churches. Although they play an important role, they are not the most prominent boundaries. They rather seem to form basic conditions which middle class Pentecostals expect from their churches in an almost natural way.

\subsection{Intellectual Refinement: Educational Boundaries}

Among middle class Pentecostals there is a strong emphasis on education. Their level of education - as well as their educational aspirations - allows them to draw educational boundaries in opposition to other Pentecostals. References to education are ubiquitous in the interviews and appear with regard to almost every aspect of the church. The importance that middle class Pentecostals attribute to education and personal development becomes particularly apparent in the organization and infrastructure of their churches as well as in the style and content of the sermons.

\subsubsection{Educated Environments: Well Educated Pastors and Members}

Middle class Pentecostals want to be surrounded by an "educated" social environment. They expect education to play an important role in their churches. In particular, the education of the pastor as the head and representative of the congregation is conceived of as essential. Therefore, pastors of middle class churches are usually highly educated, with some of them holding $\mathrm{PhD}$ degrees. Further, they not only tend to be educationally well trained, but are often also integrated in some kind of evangelical educational facility as teachers or directors.

Many middle class interviewees evaluate the quality of pastors on the grounds of their educational achievements. According to these interviewees, pastors should have a good general education and theological training, whereas 
pastors without theological training are suspected of making mistakes in the Bible teaching, the religious practices, and the management of the church. Specifically Pentecostal churches in the poor conurbano are thought to be led by pastors who lack a sufficient educational background.

Showing videos of healing practices and exorcisms from lower class churches to middle class interviewees, they argue that these churches are led by pastors lacking adequate education: this supposed lack would drive them to conduct dubious practices in their churches. Carlos' reasoning exemplifies the concept of pastoral education among middle class Pentecostals. The absence of education is seen as a strong disadvantage for the congregation and a potential threat for the Christian message and religious practice.

In many Pentecostal churches, and outside the city in the provinces, this occurs a lot. They have experiences with God, and then it's over. They read the Word a little bit, and that's it. So they are becoming cults, forming congregations thinking that God speaks to them and that God controls them (...) and they are really doing a poor job, because when you got there, you realize that they don't understand anything. They are so far away from the Word of God and the guidance that God offers us in the Bible, because of a lack of knowledge. "And because of ignorance, my people have perished," says the Word, and there is so much ignorance, in the Pentecostal church there is so much ignorance. Even though the new generations are changing a bit, it is still easier to experience God than to study the Word of God.

INTERVIEW CARLOS

Carlos refers in particular to churches located on the poor outskirts of Buenos Aires as churches where pastors lack sophisticated education. For him, the quality of pastors and their religious practices depend strongly on their educational background: it is the educational level which decides the ability of pastors to conduct religious practices in an appropriate way. Further on, Carlos distinguishes between educated Pentecostalism and emotional Pentecostalism. In educated Pentecostalism, practices are based on knowledge whereas in emotional Pentecostalism pastors and members follow their feelings when performing religious practices.

What [religious practice] is based on, now how it is done. It can be based on skill, experience and training. Or on feelings and emotions. This is the big difference. In the Pentecostal church, it is usually based on emotion. 
Also Maria shows a critical attitude towards the education and performance of pastors in lower class neighborhoods. According to Maria, many Pentecostal pastors of lower class congregations are individuals who have achieved very little in their secular lives and are now striving for recognition through their religious activity. These pastors are thought to lack the necessary training and abilities that would prepare them for their task. ${ }^{35}$

Educational preparation is regarded as an essential condition for being a good pastor. The educational training of middle class pastors is positively distinguished from the supposed lack of education among pastors in lower class neighborhoods. In this way middle class Pentecostals draw a boundary between their style of Pentecostalism and the "uneducated" Pentecostalism of others. Education is an easily applicable resource for the boundary work of middle class Pentecostals since they themselves hold higher educational degrees than do lower class Pentecostals.

Interestingly, even the pastor's capacity to perform strong spiritual practices, which are usually perceived critically, is judged according to his educational attainment. Middle class Pentecostals claim that strong spiritual practices like exorcisms should be carried out with discretion in private places apart from the church service. But performing them privately is not the only condition that they mention. In addition, those who conduct these practices should be well trained. Only those who are intellectually trained are regarded as skilled enough to perform these practices in an appropriate manner. The following quote from an interview with Camila in which she refers to a video of an exorcism illustrates this position:

There are some people who truly treat this with the seriousness that it deserves, but there are other people who have made this a circus. I reiterate that I do not agree with [the latter] and [I believe that] of course not only does a person have to be spiritually trained, but they also have to have the intellectual ability to know what they are dealing with.

INTERVIEW CAMILA

Interviewees regard spiritual practices as sensitive procedures for which actors require intellectual and spiritual preparation. ${ }^{36}$ However, strong spiritual practices

35 Interview Maria Part 2.

36 See also, Interview Alejandra. Some interviewees add to this view on exorcisms that churches should offer a professional counseling service which accompanies individuals who are affected by some kind of secular or spiritual affliction. The objective would be a long-term change in the life style of the given individual. See, for instance, Interview Emilia. 
are perceived as far less important by middle class interviewees than other practices. Pablo, for instance, claims that churches should not focus on spiritual manifestations but rather on teaching the gospel. Instead of conducting practices of liberación the church should be dedicated to Christian subjects and speak about God. ${ }^{37}$ Spiritual practices tend to be portrayed if at all as secondary in importance, whereas the transmission and understanding of the Bible is supposed to stand at the forefront of the congregation's practice.

Finally, education plays an important role concerning peer members. Some of the middle class interviewees expressed the desire to have fellow members with a similar social background in their congregation. Those who mentioned this preference were members or ex-members of lower class churches in which they suffered from a lack of peers with similar cultural backgrounds. The lack of individuals with similar cultural backgrounds was experienced as a serious disadvantage since it meant for them also the absence of friendships within the congregation. One of these interviewees is Maria. She was once a member of a lower class church and experienced difficulties in establishing friendships within the congregation. A further reason to leave this church was that she did not want to raise her children in an environment which she describes as shaped by lower class problems.

(...) I didn't like the Pentecostal church I went to very much because it was "so poor." (...) I didn't like it because (...) I couldn't identify with the people. To give you an idea, the people who go to these churches are typically women who were either abused as girls, or had two or three husbands, or have children from different men. The problem with them is that their current boyfriends molest their daughters who are from different fathers. They usually work cleaning houses and their daughters stay at home with their drunken husbands. They are from a very low social class...I'm not trying to be disrespectful, I just mean that I didn't have friends there. I saw that my daughters were going to grow up in that environment and that worried me. Or they had children that...you see I am a lawyer...they would come to me to get advice about their children who had gone to prison for theft. It's a very low social class.

INTERVIEW MARIA PART 2

A common educational background facilitates the sharing of many cultural habits and the formation of friendships within the congregation. Therefore, simply embracing an educated leadership and membership contributes to the 
middle class appeal of middle class churches. Middle class Pentecostals want to practice their religion in an educated environment, an environment that is experienced as fundamentally different from that of the "uneducated" congregations in the conurbano.

\subsubsection{Seeking and Providing Education}

The appreciation of education also becomes evident regarding the educational ambitions of middle class Pentecostals. Middle class Pentecostals strive for spiritual and personal growth which they believe can be achieved through education. For this reason, many of the middle class informants have studied at theological institutes. Some of them even earned theological degrees while others took courses to deepen their theological knowledge. Frequenting Bible courses and undergoing theological training is often related to the ideal of personal development. ${ }^{38}$ Camila, for instance, seeks development as she says: "I am searching for development, a devolopment in my relationship with God (...)." (Interview Camila)

The middle class churches that I studied also place a strong emphasis on education in their organizational offerings. Bible courses are a must. Some congregations collaborate closely with Bible institutes to develop their course program. In these courses, Pentecostals can study different topics concerning the Christian faith.

The Iglesia Biblica Cristiana, for instance, offers courses on the life of Paul, the early years of Jesus, as well as training courses for future Sunday school teachers and personal counselors, and courses on what they call anthropological theology which are dedicated to self-discovery called "La persona que soy" ("The person that I am") and "Descubre tu camino" ("Find your way").

Other educational facilities that one can find in many middle class churches are Christian kindergartens and primary schools, and in some cases even secondary schools. Moreover, middle class churches offer Sunday schools for children and teenagers. For middle class congregations it appears to be an important feature to have their own educational facilities to which members can send their children. Another feature contributing to the educational aspirations of middle class churches is the book store. The book store sells aside

$38 \quad$ For instance, Mateo explains that he took a number of courses in his church in search for personal development (Interview Mateo). 
from Bibles, music CDs, and the latest issue of El Puente or El Corriente a variety of evangelical books from Anglo-Saxon authors. ${ }^{39}$ In this way, the educational aspirations become apparent in the form of organizational boundaries as discussed in the previous section.

\subsubsection{Educated Ways of Preaching: Education and Development in the Sermon}

The sermon is another aspect in which the aspiration for education becomes apparent. Middle class congregations place a strong emphasis on the sermon: the sermon is at the heart of the congregational practice and makes up by far the most important part of the church service. Sermons are generally longer, show a clearer structure, and engage a more intellectual style of preaching than in other Pentecostal churches. ${ }^{40}$

\subsubsection{A Refined Style of Preaching}

Preachers of middle class churches tend to make an erudite appearance during sermons. Many of them apply an almost academic style which makes the sermon resemble in extreme cases an academic lecture. Different techniques contribute to the erudite appearance of preachers and make their sermons appear more intellectual than those of other Pentecostal preachers.

First, the use of language differs from that of other preachers. Preachers speak in a clearly articulated Spanish without much of the typical Porteño accent. They often use refined vocabulary and more abstract terminology as well as loan words, particularly terms from ancient Greek and Hebrew. Further, preachers frequently apply metaphors.

39 Some lower class churches also offer a bookstore-like facility. However, these facilities more often sell sweets, potato chips, and soft drinks than books. The few books that they offer tend to be older and often look like they have already spent a long time in the window display.

40 In many Pentecostal churches the structure of the sermon and the main message are often less evident for middle class observers. Shifts between different topics are frequent. Pastors may also switch between the oral discourse of the sermon and physical activities that involve the audience. They may ask the audience to repeat certain phrases or carry out specific activities after which they return to the oral discourse of the sermon. Thus, sermons tend to form a mix between the oral discourse of the pastor and physical activities integrating the audience. The oral discourse is in many churches shaped by the concepts of spiritual warfare and prosperity gospel. Often the focus of the sermon lies on improving daily life, which is supposed to be achieved by blessings of the supernatural, particularly miracles. 
Second, preachers use references and side notes which show that they have command over a large amount of historical, scientific, and theological knowledge. They sometimes insert references to famous scholars, particularly philosophers, or theories. Providing background information is another important characteristic. Middle class preachers provide vast and concrete information about the historical context of the Bible story.

An intrusive example for this tendency occurred in Iglesia del Libertador. Iglesia del Libertador is a middle class church located in an upper middle class neighborhood in the north of the city of Buenos Aires. During one sermon the preacher explained at length James Fowler's faith stage theory to his audience. He presented a detailed description and examples for each faith development stage. More frequently, preachers provide historical background information for a Bible reading. Pastor Mraida from the Iglesia del Centro, for instance, presented during a church service a lengthy explication of a Jewish purification ritual and provided the Hebrew word and a Spanish translation for each of the components of the ritual.

Third, middle class preachers tend to use techniques which transmit an image of exactitude and lend an almost scientific appearance to the sermon. For instance, sometimes preachers focus on one sentence from the Bible and compare different possible meanings of the sentence or a word in the sentence in order to discover the real meaning of the phrase. This technique suggests that the objective is to find the exact meaning of each phrase and not just to read the Bible. Moreover, it insinuates that the pastor exerts a distinguished and more sophisticated form of reading and interpreting the Bible.

Fourth, a controlled use of the voice transmits an image of being measured and thoughtful instead of being emotional. Middle class pastors generally preach in a quiet and controlled voice. They may raise the voice or speak faster in order to underline parts of their argument, but they usually abstain from shouting.

Fifth, preparation contributes to an image of professionalism. Some middle class preachers orient their sermon on notes that they prepared for the sermon. Several middle class preachers also apply modern technology in order to impart their message. They project central points of their message as an electronic presentation on the wall behind the pulpit. This method allows everyone to follow the central argument and creates a professional appearance.

Finally, their almost academic style is loosened by the use of humor and irony, often self-irony. Middle class pastors occasionally make jokes about themselves, the habits of Protestants, or Argentinean culture. 
An important element of sermons is reference to the Bible. All middle class pastors I interviewed explained to me that a strong Bible basis was the central characteristic of their sermons. Therefore, during sermons there is an extensive usage of Bible references. Middle class preachers start their sermon with a comparatively long Bible passage. They read the Bible passage out loud, which may at the same time be projected on a wall behind the pulpit. After this, they begin with an interpretation of the Bible passage, relating it to everyday life. Finally, they end the sermon with some conclusions. In total, the Bible exegesis is an essential element of middle class sermons.

\subsubsection{The Message of the Sermon: Personal Development and Assuming a Pro-Active Position}

The ideal of education and development also appears as a topic in the content of sermons. The content of the sermon varies from church service to church service and tackles a wide variety of topics. Nevertheless, there are quite a few similarities in the discourse of middle class preachers. Common topics of sermons include moral improvement, personal development and self-realization, establishing a pro-active attitude, and improving society. These topics are often related to education and personal development.

Pastors frequently address the topic of personal development. In particular, the role of education, wisdom, and the necessity for self-improvement are stressed: faithful Christians should train themselves in order to be prepared for the challenges they face as Christians in modern society. Further, the idea of constant personal development is often combined with the concept of providence: God has a purpose for every individual and vests each individual with specific skills to fulfill this purpose. According to this view, one should train these skills in order fulfill one's divine purpose in the best possible way. It goes without saying that this discourse encourages continual self-improvement and the search for excellence. ${ }^{41}$

The "development discourse" also embraces the idea of moral development and improvement. Middle class pastors frequently stress the need to regret one's sins and to morally improve oneself. The moral discourse can be combined with the demand to be pro-active: ${ }^{42}$ Christians should assume a pro-active posture

41 For instance, the preacher from Iglesia Cristiana Biblica calls the audience to actively use the talents that God gave them and to multiply them (Iglesia Cristiana Biblica 1oth April 2011). Additionally, for the idea of providence and action for God, see Iglesia Peniel: 1st May 2011. The lack of Christian values and the existence of harsh inequalities and injustice are frequently criticized in middle class sermons. Preachers state that Christians should try to impact society and change it: they should shape society with their Christian values and behavior, instead of being shaped by society. 
with regard to society and their own lives. In order to govern their lives and social environment pro-actively, pastors encourage them to develop their professional skills. Again, the importance of education and professional training becomes central.

During a sermon in the Iglesia del Centro, Pastor Mraida points out that devotees have to assume responsibility for their lives and should act in a pro-active manner. Instead of stressing the possibility of divine interventions in support of devotees, he argues that devotees have to work out their lives and prepare themselves for the future. A central element of this preparation is lifelong learning. In some cases, pastors may even seek to transmit specific skills to their members, as in Iglesia del Centro where the pastor explains in a specific evening service how to plan, realize, and control the success of business projects. ${ }^{43}$

Hence, the discourse of middle class pastors stresses a specific range of values: self-realization, self-development, and pro-active attitudes that are closely related to education and learning. Christians are expected to fulfill God's purpose and to behave at the same time in a pro-active way by governing their lives and their social environment. Their strategy for achieving this goal is through education and training. ${ }^{44}$

\subsubsection{Education as a Resource for Middle Class Boundary Work}

Education is a highly valued good in the middle class. Drawing boundaries on educational grounds appears to be a typical characteristic of the middle class. Therefore, it is not surprising that middle class Pentecostals repeatedly refer to education and draw boundaries between the educational standards of their churches and the supposed lack of education in other Pentecostal churches, mainly those located in the poor neighborhoods of the conurbano. However, the intensity and frequency with which middle class Pentecostals refer to education is astonishing. Education plays a central role in many areas of the church. It is considered important with regard to the (secular) services of church (Bible courses, schools etc.), leadership, other members, spiritual practices, and the sermon.

43 See sermons of Iglesia del Centro, 17th April 2011 and Iglesia del Centro o1st May 2011.

44 Nevertheless, middle class churches do not only emphasize this life. Salvation - or: the afterlife - is generally portrayed as the final destiny and objective of evangelical faith. Yet, salvation is not regarded as a question of achievement, but of predestination. 
The strong emphasis which is placed on education may be due to the fact that the possession of and affinity for education constitutes a central boundary of the Argentinean middle class. Education is - by definition - an aspect that is more pronounced in the middle class. Being a resource that is "naturally" given in the middle class, it lends itself for drawing and underlining differences with regard to those who are perceived to be less educated or "ignorant", namely lower class Pentecostals.

\subsection{Moderating the Spirits: Expressive Boundaries}

(...) the higher one's place in the status pyramid, the smaller the number of persons with whom one can be familiar, the less time one spends backstage, and the more likely it is that one will be required to be polite as well as decorous.

GOFFMAN 1959: 133

Plus la situation est tendue, formelle et plus le locuteur tente de se conformer au style (...) le plus légitime.

LAHIRE 2001: 78

Expressive boundaries refer to the visible performances of participants and pastors during church services. Performing Pentecostalism in a less expressive and emotional way, middle class actors draw expressive boundaries. Their religious performances are marked by an adaptation to middle class standards of appropriate behavior. They seek to distinguish themselves from other Pentecostals whom they experience as uncontrolled, emotional, and noisy. Expressions of Pentecostalism which are experienced as potentially shameful are widely banned from the church service. The tendency for banning "inappropriate" aspects from the public sphere of the church service becomes apparent in the general atmosphere of church services and its spiritual practices, as will be shown in the following subsections.

\subsubsection{An Atmosphere of Good Behavior}

The ambience of Pentecostal church services in Latin America is widely known. Latin America's Pentecostal churches are notorious for their expressive and emotional atmosphere. Correspondingly, one can also witness a highly expressive emotional atmosphere in many of Argentina's Pentecostal churches which can become apparent in various ways: dancing, singing, shouting, crying, trembling, speaking loudly in tongues, and manifesting evil spirits. Church 
services generally embrace a wide range of emotions from joy, happiness, contemplative moments, ecstasy, crying and relief. Particularly the musical praise is a moment of festivity and joy. The most popular styles of music are Christian rock and pop, cumbia, and folk music. The majority of songs are motivational and cheerful. The audience sings out loud, claps their hands, raises their arms, and may sometimes even dance or jump to the rhythms. Frequently, smaller churches provide rattles to their members with which they accompany the songs. These elements create an enormously festive and cheerful atmosphere.

Songs frequently praise the power of the Holy Spirit and its coming ("Ven Espíritu!"), thank God for his support and call Him to heal, and celebrate the defeat of the Devil. A very typical song in lower class church services invites the participants to let the Holy Spirit flow and sings "Dejalo que se mueva, dejalo que se mueva, el Espíritu de Dios!" ("Let the Spitit move"). The song gets faster and louder with each refrain and ends in a speedy and loud sound to which people sing and dance. ${ }^{45} \mathrm{In}$ El Redentor, a lower class church located in a slum in the surrounding area of Buenos Aires city, the song was interpreted by the church band. The singer used a lot of gestures and moved the pulpit up and down like a rock singer while he sung in an emphatic voice. During the refrain he started to jump and suddenly danced with the pastor on the pulpit. The people in the audience also started to jump and dance. A bunch of elderly ladies ran to a free space in front of the pulpit in order to dance there. At the end of the song participants applauded and called out loudly in jubilation. The singer shouted into the microphone while music kept playing "Yes, lord! The Spirit of God is moving this night! The Spirit of God is moving this night! Umbabababababa [speaking in tongues] Uuhhhhhuuhhhhhh! Yes, lord! Yes, lord!" The audience exalted loudly and many participants raised pieces of cloth and swung them around like a flag.

Also during the sermon and prayers, there are different elements that contribute to the expressive atmosphere. The audience, for instance, may occasionally shout "Gloria!", "Amén!" or "Aleluya!" and raise their arms or the pastor may

45 Other popular songs of lower class churches are, for instance, "Asi se alaba a Dios con mucha alegria y gozo!" or "Espíritu de Dios, llena mi vida, llena mi alma, llena mi ser, Espíritu de Dios llena mi iglesia, llena mis hermanos, llena mi ser, y llename, llename, llename con tu presencia, llename, llename, llename con tu dulzura, llename, llename, llename con tu poder, llename con tu poder." These songs, for instance, were played in a congregation of Centro Cristiano in a slum in the city of Buenos Aires. See video 7112 and 7133. 
raise his voice strongly and start to shout. In particular, spiritual practices such as faith healing and prayers can be very expressive and lead to ecstatic states in which the audience speaks loudly in tongues, trembles, and may fall to ground. All these elements create an atmosphere that is highly expressive and often described as noisy by middle class Pentecostals. ${ }^{46}$

A Pentecostal branch which had recently opened when I started my field research was Ministerio Apostólico Jesús Varón Guerra y Libertad. For this reason, I had the opportunity to accompany the church in its development. An old, sparsely decorated craft hall served as a temple for the small congregation. Between 10 and 40 members attended the church services regularly during my research. The atmosphere was always very lively, particularly during the praise when the pastor imitated Christian songs with cumbia and Carribean rhythms in a playback mode. During these moments the church converted into joyful celebration in which members sung loudly and danced through the hall. But also during sermons and prayers the atmosphere became emotional and expressive with members shouting repeatedly "Gloria!" ("Glory!") Preachers frequently engaged interactive elements in their sermons and asked the audience "Cuantos dicen gloria a Dios?" "How many of you say > glory to God < ?") which was answered in a loud voice "Gloria a Dios!" ("Glory to God!") and then the pastor asked "Y a su pueblo?" ("And for his people?"), whereupon the participants shouted "Victoria!" ("Victory!"). This performance was repeated over and over again during sermons. The Holy Spirit was an important element in the sermon as well as in religious practices. Depending on the church service, strong spiritual manifestations and exorcisms took place. During prayers participants spoke loudly in tongues and trembled. At the end of the church service pastors laid hands on the foreheads of participants while some of them dropped to the ground.

By contrast, in middle class church services, the atmosphere tends to be different. Here, the audience manifests their emotions less openly. The general style of the church service is calmer, more sober and characterized by a limited degree of physical and emotional expression. During the music, members may sing and some may stand and raise their hands a bit. Yet, the general atmosphere remains comparatively quiet.

46 Many middle class pastors described lower class Pentecostal churches as rather noisy. 
A very typical pop ballad for a middle class Pentecostal church, for instance, is "Canta al Señor toda la creación" by Danilo Montero. The song is a mix between a pop song and a very melodic hymn. The text praises God's majesty and power and announces an unlimited love for Him. This song is played, for instance, during a church service in the middle class church Iglesia del Libertador: the song is interpreted by a band that consists of the main singer, two background singers and a small choral group, a drummer, a guitarist, a bassist and a saxophonist. The singer, a young man dressed in casual clothing, stands at the pulpit and sings in a calm voice while he sways slowly to the rhythm of the music. The vast majority of audience sits on their places and quietly listens to the music, whereas only a very few participants stand up and sing. Some among them very cautiously raise an arm while they sing. The atmosphere is very controlled and appears to be almost stiff.

In the rare cases that they say "Amén" or "Gloria a Dios" ("Glory to God!"), participatns pronounce these exclamations in a much softer and discrete voice. At the same time, the audience shows lower degrees of physical and emotional involvement. States of ecstasy are widely absent. Participants do not tremble, speak loudly in tongues, or drop to the ground. They control and limit their physical gestures and expressions. Not only participants but also pastors limit their expressiveness. Pastors do not yell or speak in tongues, and seem to avoid strong emotions. There appears to be a non-verbalized consensus about the limits and appropriate forms of physical expression during the church service. This consensus prohibits "outbursts" and "uncontrolled" behavior and limits the expressivity to a certain level and to specific contexts. Interestingly, Pastor Oscar stresses the importance of free expression during church services: devotees should be free to express themselves as they want. ${ }^{47}$ Yet, at the same time he points out that the church wants to maintain "a certain image" with regard to church visitors who do not form part of the congregation. Therefore, his congregation would not encourage desbordes (exaltations) - such as shouting or people dropping to the ground - as they use to happen in many Pentecostal churches:

If we conduct religious practices where we think people may fall down or manifest the Spirit in some way, we do it after the service, not during the 
service. This is to prevent projecting a certain image to people who are not part of the congregation. We don't pray all together, but we do say, 'We are going to pray for each other,' and you'll hear the person next to you praying quietly. In Pentecostal churches, people yell, there are very dramatic expressions of the Spirit. But these transgressions, so to speak, wouldn't occur in our church.

INTERVIEW PASTOR OSCAR PART 1

Charismatic practices that may disturb other visitors of the church are not carried out during the church service but in specific spaces apart from the church service. By separating potential desbordes from the public sphere of the church service, the congregation wants to maintain a "certain image", an image of order and respectability.

The quotes from Pastor Oscar illustrate that the risk of outsiders, nonPentecostal class peers, entering the scene is always present in the mindset of the congregation. It does not matter if an outsider is really present. The possibility of an outsider paying a visit is sufficiently worrying. Middle class Pentecostals do not want to be caught unawares when performing inappropriate practices. For this reason, they have to be prepared for potential visits and orient their religious performance to standards of appropriate behavior. It seems like the non-Pentecostal class peer is experienced as always being present and judging the appropriateness of the behavior of its class peers.

However, not only the potential presence of non-Pentecostal peers leads to the adoption of a socially more acceptable style. Also the preferences that many middle class Pentecostals communicate lead in this direction. Interviewees explained to me that they prefer a calm atmosphere during church services. They dislike the loud atmosphere and shouting which many of them have already experienced personally in other Pentecostal churches. Some of the informants state that they would not affiliate with a congregation in which the pastor or members shout. Other interviewees relate shouting to the effervescence of emotions of which they disapprove. Emotions are regarded skeptically. Middle class Pentecostals appear to dislike the open manifestation of emotional states in the church service. Real faith is described as something different from human emotionality. Luis, for instance, claims that faith should not be an emotion but a conviction:

I don't like it when things get overly emotional, when faith becomes something emotional, I don't like it. Faith should be a conviction in my life, in my thoughts.

INTERVIEW LUIS 
It seems like Christian faith is perceived as something that should be practiced in a rational rather than an emotional manner. Emotions tend to be rejected in the statements of middle class interviewees. ${ }^{48}$ Middle class Pentecostals appear to prefer the exclusion or at least subordination of emotions in the congregational practice.

Moreover, middle class respondents who are affiliated with socially mixed congregations do not welcome the expressive style of some of their fellow members. They perceive an expressive style as the attempt of fellow members to publicly simulate a personal relationship with God. The rejection concerns physical expressions such as dancing, raising arms, and shouting exclamations like "Gloria a Dios!" and "Amén!". Participants, by contrast, should rather limit their expressions, according to the view of middle class interviewees. One example is Fabian. He participates in a mixed church and dislikes the expressive style of some of his fellow members. According to Fabian, devotees should not dance in the Spirit in public. He prefers that they express these forms of adoration privately. ${ }^{49}$ Another example is Eduardo. Although he does not claim that it is wrong to be expressive, he dislikes other believers around him being very expressive. ${ }^{50}$ Therefore, he depreciates the the shouting of expressions such as "Gloria a Dios!" in Pentecostal church services. There is a general rejection of expressive religious styles which is shared by most of the middle class interviewees.

But there are also exceptions. Isabella, a member of AC, stated that she prefers a more expressive style of worship. She would like her congregation to be more expressive. She describes her peer members in AC as restraining the Spirit:

Look, when someone says that he is Pentecostal he lets the power and the joy of the Holy Spirit flow...I would say that here, at this church, Assembly of Christ, there is little flowing. I mean, it's not because of the Holy Spirit. It's just that people here are stiff, cardboard almost, very 'I'm not going to open up, because the person next to me will look at me and say, 'What's wrong with you?' (...) Why do they have to have their hands in their pockets, their mouths closed, and with an expression on their face that makes you think, 'Wow, he's really into it,' 'Ahhh yes, because the Lord...' with their foreheads and faced scrunched up. (...) Don't sing too loud, you

48 See also Interview Mateo.

49 Interview Fabian.

50 Interview Eduardo. 
shouldn't be too jubilant, you shouldn't clap too much, you shouldn't yell (ahhh). It looks bad, you shouldn't jump.

Although she exhibits in other parts of the interviews a very critical position towards the spiritual manifestations, she states here that she would prefer her congregation to be more Pentecostal in its religious expression. She regards her peer members as limiting their expressions and abstaining from practices that "queda mal" (make a bad impression) due to the fear of being perceived as strange or inappropriate by their peers. Being fed up with this type of acting, she criticizes her peer members for exercising self-control from which she wants to break away. The case of Isabela shows that middle class Pentecostals may also suffer from the social constraints which control and limit the expressivity of their religious practice. Nevertheless, being a member of AC, Isabela adapts herself to its modalities of expression. Even she reports to limit her expressions in the church service of AC and to behave in a more expressive way when visiting other churches outside the city of Buenos Aires. The case of Isabela indicates that middle class devotees do not necessarily practice Pentecostalism according to their personal affinities but adapt their religious expressions within the sphere of the middle class church service to what they believe others will regard as appropriate.

The majority of middle class Pentecostals adapt themselves to a less expressive style. Most respondents describe their own religious style, in comparison to the style of other Pentecostals, as rather quiet and calm. They state that they neither shout, nor raise their arms or dance. ${ }^{51}$ The comments from an interview with Pedro illustrate the widespread disapproval of an expressive style of Pentecostalism. He describes himself as rather reserved and dislikes manifesting his relationship with God publicly in front of other individuals. He prefers, instead, having an intimate and private relationship with God.

It seems excessive to me, raising your hands, kneeling, or praying in a loud voice (...) Personally, I don't feel comfortable when things like that are happening around me, because it's just a question of preference. I am a little more private, more reserved. I try to have a relationship with God, and I don't have any reason to display it to the person next to me. I don't like it; it's what makes me uncomfortable...but I'm in no place to judge anyone.

PEDRO 00:26:54-00:29:10-6

$5^{1}$ Three examples are Ana, Nadia and Miguel (Interview Ana Part 1, Interview Nadia, Interview Miguel Part 2). 
This unease with publicly expressing one's relationship with God is shared by the majority of my middle class respondents. Intimacy and discretion play a central role in their religious tastes and practices. The church service is not experienced as the appropriate sphere to express emotions and a personal relationship with God. For this reason, many of them prefer to have small groups or personal meetings with their pastor in which they can express themselves and discuss their problems in a more discrete environment.

Middle class churches may offer specific physical or temporal spaces in which a higher degree of emotion and expressivity is accepted. Middle class pastors informed me, for instance, that they would carry out exorcisms, if necessary, in more intimate spaces apart from the church service. Another environment that offers a space for more emotional and physical expressions are smaller church groups. Some churches offer, for instance, "camps" in which a group of members assembles to spend a weekend together in a closed location outside the city of Buenos Aires. Interviewees described these surroundings as emotionally more intense. However, during the church service there are also particular moments that are more intense. This is specifically the case at the end of the service. Some middle class churches perform a prayer and sometimes a laying on of hands at the end of the church service. This is generally the moment in the church service that most encourages an emotional and/or spiritual experience and provides a context in which participants can express their emotions more openly. Yet, also during this moment emotional and physical expressions remain much more limited than in other churches. ${ }^{52}$ The audience acts calmly. Participants do not shout, tremble, or show any other

$5^{2}$ An exception is the church Iglesia Peniel. While the general style of the church service is calm and resembles that of other middle class churches, there is a specific moment that sometimes occurs at the beginning of church services. This moment provides a context that allows members to express their emotions. It starts at the end of the musical praise: while the music plays and a large part of the congregation stands in front of the pulpit, individual members go up to the stage and declare their problems. During this practice they may shout and cry. This contributes to a highly emotional atmosphere. After this moment, the sermon begins and the atmosphere becomes totally quiet. No one shouts "Gloria a Dios" or other expressions. The church service creates a specific space for the expression of emotions, while the rest of the church service is dominated by a style that one can also observe in other middle class churches. According to members of the churches, this moment happens without planning and only very rarely when members feel the need to express their grievances. The existence of this practice appears to be encouraged by the fact that Iglesia Peniel is a more closed community and perceived by members as a more intimate space than other churches. Here members feel encouraged to express emotions that they would otherwise only express in small groups. 
type of pronounced physical and emotional involvement. They stand quietly. Some among them raise their arms or go to the pulpit to kneel and pray. A few among them may cry quietly on their own.

However, there were also exceptions of single individuals who were more devoted than the general audience. I observed one of these exceptions in a branch of the Asambleas de Dios in Flores (on San Pedrito Avenue), a congregation with around 400 active members mostly from middle class neighborhoods in and around the district of Flores. The atmosphere was generally rather quiet during the church service and only a few members spoke quietly in tongues. But one member stood out during my observations: he spoke loudly in tongues during prayers and his loud interjections of "Gloria!" and "Amén!" during the sermon seemed to irritate some of his fellow members. His actions stood in contrast to the general behavior of the audience and illustrated the type of behavior that was perceived as normal in this middle class church. After the sermon I approached him and found out that he was from a slum where his main church was located. Thus, his noticeable actions during the church service may be related to the fact that he was affiliated with a different branch of Asambleas de Dios in a very poor neighborhood that probably performed a different style of Pentecostalism. His way of acting exemplifies the contrast between the "inappropriate" style of Pentecostalism and middle class Pentecostalism.

I made similar observations with middle class Pentecostals in lower class churches. In one case I visited a lower class church in the surroundings of Buenos Aires city together with two middle class Pentecostals who were affiliated with different churches. A lower class Pentecostal who was a friend of a friend of these two middle class Pentecostals and a member of the church had invited us to visit his church. Thus, we participated one Sunday evening in the service. While he and the majority of the audience were engaged in the repetition practices the pastor was asking them to carry out, the two middle class Pentecostals were much more reluctant to perform the repetition practices and to show any sign of emotional involvement. They refused to perform the repetition practices and showed no emotional expression while the audience was clapping their hands loudly and exclaiming "Gloria!".

Altogether, physical and emotional devotion tends to be less pronounced than in other Pentecostal churches. One can observe a more controlled type of Pentecostalism. Participants appear to control and limit their physical gestures 
and expressions. There seems to be a non-verbalized consensus regarding the limits of physical expression. This consensus prohibits "outbursts" and "uncontrolled" behavior and limits expressivity to a certain level and to specific contexts. Nonetheless, participants' emotions can be expressed in specific moments of the church service if they remain controlled and limited. "Uncontrolled" emotions and "outbursts", instead, are banned from the public sphere of the church service and are delegated to the private sphere. The privatization of "inappropriate practices" will be discussed in the next subsection.

\subsubsection{Restraining the Spirit}

One of the central characteristics of Pentecostalism is its emphasis on the Holy Spirit and its gifts. The emphasis on the Spirit can express itself in a variety of practices during the church service. The most important among them are perhaps the speaking in tongues, faith healing, and exorcisms. ${ }^{53}$ Yet, these practices are widely absent in the services of middle class congregations. In fact, the performance of these practices is often not very welcome in the public sphere of the church service. ${ }^{54}$ Spiritual practices that are strongly rejected are public exorcisms and other types of spiritual warfare. Middle class Pentecostals have an ambivalent relationship with regard to spiritual warfare. Pastors of middle class congregations believe and support the concept of spiritual warfare. ${ }^{55}$ Although they seem to be comfortable with the concept of spiritual warfare, references to evil forces are almost entirely absent in their church services. ${ }^{56}$ Moreover, middle class pastors reject the performing of exorcisms during church services as scandalous and unaesthetic. In their view, churches should protect the privacy of their members and remove them in the case of a demonic

53 See Anderson 2004: 30; Chesnut 1997: 6, 47; Corten 1995: 10-12, 153-154; Freston 1998: 340; Mariz 1994: 67; Lehmann 2003: 479; Luca 1999a: 9-10; 2008b: 29-30; Parker 1996: 142; Schäfer 1998: 67; 2009: 567; Wynarczyk et al. 1995: 7-8.

54 Middle class churches do not seek to spur manifestations of the Spirit nor miracles during their church services. This attitude includes faith healing the speaking in tongues. Practices involving the idea of spiritual healing are limited to prayers and the laying on of hands at the end of church services.

55 Interview Pastor David; Interview Pastor Alejandro.

56 Only very rarely - if at all - do pastors mention demons or Satan and call to fight these forces. Moreover, many middle class informants reject the overuse of references to demons and Satan. According to them, God should rather stand in the center of the church service instead of malicious spirits. One of those who criticize the overuse of these references is Marta. She argues that Pastor Juan Crudo attributes too much importance to Satan and demons (Interview Marta Part 2). 
manifestation from the public sphere of the church service into a more intimate space. ${ }^{57}$

Lay members of Pentecostal churches also adopt a very critical attitude towards exorcisms in church services. I showed different videos of exorcisms and healing practices to middle class interviewees. The reactions to these videos were negative, ranging from rejection through indignation to laughing and mocking the way in which these practices are carried out. These practices are not perceived as appropriate in relation to wider society. Middle class Pentecostals argue that they cannot bring non-Pentecostal friends or neighbors to such church services without feeling ashamed and being described as insane. Thus, there is a demand to adapt Pentecostalism to social norms of appropriateness and decent behavior. Pentecostalism is requested to adapt to forms of expression that are experienced as acceptable by peers. According to these demands, the church service should be performed in a way that is also perceived by non-Pentecostal peers as appropriate and convenient. Expressions and practices that do not fit this condition are moved to a more isolated, private sphere.

Also with respect to the integrity and intimacy of the individual, middle class Pentecostals claim that these practices should be carried out in separate spaces. They argue that performing exorcisms in the public sphere of the church service could expose and humiliate the affected individual. In order to protect the dignity of the individual, interviewees want these practices to be carried out in a more private context. Maria expresses dissatisfaction while watching a video of a GIL exorcism. She describes the event as a show. Instead of drawing the public attention to the spiritually afflicted individual, she would try to withdraw him/her from the public scene of the church service. ${ }^{58}$ Exposing the person in this state to the public is perceived as a humiliation. In order to avoid situations of exposing a possessed individual to the public and letting him/her potentially face public humiliation, respondents prefer exorcisms to be practiced in a discrete manner in private places.

57 Pastor Oscar, for instance, believes that exorcisms during the service would be scandalous and affect the orderliness of the service (Interview Pastor Oscar Part 2). Pastor Alejandro fears that public exorcisms could affect the person's dignity and would turn into a show (Interview Pastor Alejandro). Besides the intimacy of the individual, Pastor Manuel also names aesthetic and spiritual reasons. Yet, performing an exorcism in public is not only regarded as unaesthetic and unethical but also as spiritually dangerous (Interview Pastor Manuel).

$5^{8}$ Interview Maria. 
Middle class Pentecostals are not only reluctant with regard to exorcisms but also with respect to other practices involving the Holy Spirit. Another practice that is strongly questioned is the display of miracles during church services. Although middle class Pentecostals do not reject the sharing of narrative testimonies, they disagree with demonstrating miracles during church services. Comments that I received on a video showing faith healing practices in GIL illustrate this preference. In this video, GIL pastors announce that miracles have occurred. They show the healed individuals to the audience and relate their emotional states to the public. Watching this video, Pedro disapproves of the form in which the testimonies are presented. He dislikes the fact that pastors narrate the miracles and the emotions of the individuals in question. ${ }^{59}$ Interviewees prefer instead a Pentecostalism in which miracles assume a less prominent place and in which miracles are sought and communicated in a discrete, less noisy form.

In contrast to middle class congregations, in many other Pentecostal churches manifestations of the Holy Spirit are more welcome since they are usually conceived of as a demonstration of the spiritual authority of the congregation. Consequently, manifestations of the Holy Spirit and the spiritual practices related to it such as speaking in tongues, faith healing practices, and exorcisms are more prevalent than in middle class congregations. The public practice of exorcisms, however, is not a general characteristic of Pentecostal churches. Some Pentecostal churches emphasize exorcisms and other techniques for spiritual healing whereas other churches perform these practices only occasionally during church services or in smaller groups. These practices are thought to help overcome different kinds of suffering. ${ }^{60}$

59 Interview Pedro.

6o Middle class sermons also address the topic of suffering. Yet, the topic of suffering is tackled in a different way than in other churches. While many Pentecostal churches normally present suffering as the product of a spiritual affliction which can and should be solved by divine intervention, some middle class pastors paint a different picture of suffering. These preachers do not deny that God may help the individual to overcome his/her suffering. But they tend to describe suffering and problems as a normal part of empirical existence and more particularly as something that may fulfill a divine purpose in the life of the individual. A pastor preaches, for instance, during a Sunday church service in Comunidad Cristiana that Christians should not be afraid of suffering: suffering will come one day or another and help the individual to experience and purify him-/herself, while the love of God would allow the individual to support the suffering and even to relax in the middle of his/her problems (Comunidad Cristiana 29th May 2011). Also, a preacher in Iglesia del Libertador explains that the diseases from which he suffers are a divine purpose which allow him to strengthen his faith (Iglesia del Libertador 05th June 2011). Suffering is 
Following an invitation, I visited a branch of "Iglesia Evangelica Misionera" in a lower class neighborhood outside Buenos Aires in Villa Lanus Oeste. The congregation in Villa Lanus Oeste had around 200 active members. Church services took place mainly at night and started generally with cheerful pop and folk music to which people would raise their arms, sing and sometimes dance. Lay members were actively integrated in church services by leading prayers and making announcements. The atmosphere was expressive: prayers were very intense and people spoke powerfully in tongues. For one Sunday night service, the congregation had invited a travelling apostle who performed a wide variety of healing practices and miracles. One of these healing practices concerned the change of dental fillings in the mouth of the participants through a prayer. Participants were asked to stand in front of the pulpit and to put their hands on their mouths. The apostle started praying intensely. During his prayers he yelled occasionally in a loud and screechy voice demanding God to change the cheap fillings into fillings of gold and silver, repeating over and over again: "Muela de plata, muela de oro, Se realiza. Se realiza. Se realiza. Ahora!" ("Silver inlays, gold inlays: they become reality. They become reality. They become reality. Now!") The majority of the audience prayed with him. Many of them trembled and spoke in tongues while pressing their hands strongly on their mouth. After the apostle stopped praying many participants seemed to be still in a state of ecstasy. The apostle called each individual who had cheap fillings to come to the front where he checked with a flashlight whether the fillings had changed to silver or gold. On many occasions he announced that the fillings had changed, showing it to other participants while the audience applauded cheerfully. Other healing practices and miracles were concerned with quitting smoking, a rain of gold and diamonds from the ceiling, and healing from physical illness. The congregation had announced this event as

described as a test ("prueba") and an experience which helps to develop one's character and relationship to God. Hence, God is portrayed as not always relieving devotees from their afflictions. Suffering is conceptualized as forming part of empirical life. This approach changes the focus from overcoming suffering to dealing with suffering. For dealing with suffering, particularly its acceptance as a divine purpose may provide some relief, while the hope of overcoming the suffering is not totally eradicated. The objective is to find one's peace and personal equilibrium despite suffering from an affliction. Although middle class preachers seek to impart a meaning to suffering, they may also apply spiritual practices which address the suffering. While they publically abstain from practices of faith healing and exorcism to address these problems, they use prayers to deal with illness and suffering. 
the night of miracles. The small church building was completely full with more than 200 visitors, many of them standing outside to watch through the door to the church. Despite the fact that this event was not a daily one, participants were familiar with the ideas and practices and actively engaged in them. Spiritual practices of this kind would be hard to imagine in the middle class congregations of my sample.

While strong spiritual practices are generally conceived of as inappropriate by middle class Pentecostals, there are some spiritual practices which they accept. This is the case with a spiritual practice that respondents watched in one of the videos during the interview. The video shows a spiritual activity at the end of an AC church service. In this video AC members approach the pulpit where they kneel down in order to pray. They are attended by pastors and obreros who speak or pray quietly with them. Meanwhile, a soft pop ballad is played and the rest of the congregation stand in the back at their places and listen to the music and/or sing.

Middle class interviewees described this practice with very positive adjectives. Many approved of the fact that participants and their problems are not displayed in public but treated discretely in a more intimate and respectful atmosphere during this practice. Susana, for instance, likes the practice of AC because the attention is not drawn to the devotees who pass to the front for a prayer. Instead, pastors and obreros attend each person individually while the rest of the congregation is focused on the music.

Interviewer: Why does it seem nice to you?

Susana: Because they go up front, and if you compare it with our way, they go to the front and pray calmly, speak intimately with God. It seems like...and there is the pastor to help them, who prays for them. It seems like they are in a relationship with God. It doesn't look like they are trying to show off or attract attention. Meanwhile everyone is singing, so people's attention isn't focused on those who are up front. People keep praying, worshipping, while those who need to go up front and pray.

INTERVIEW SUSANA

The practice is perceived as more authentic and less exaggerated than the healing practices and exorcisms. Pedro indicates that he likes this type of practice because there is no exaggeration or show. He regards it as a more natural, more human type of spiritual practice. ${ }^{61}$ The practice shown in the video can

$61 \quad$ Interview Pedro. 
be understood as a functional equivalent to the practices of faith healing and exorcisms that are carried out in other Pentecostal churches. Although acting as a functional equivalent for the unpopular spiritual practices, this practice is described in widely different terms than the exorcisms and faith healing practices in GIL. The activity in AC is not only experienced as positive, but is the video that middle class interviewees most appreciate among all the videos which I showed to them during the interview. They attribute positive characteristics such as intimacy, authenticity, and respect to the activity shown in the video. The activity combines a rather sober and controlled but still emotional style with a spiritual practice. In this way it is experienced by middle class interviewees as a more decent practice which does not - in contrast to many other spiritual practices - overstep the limits of appropriateness. To remain within the limits of appropriateness appears to be an essential criterion for middle class Pentecostals. If activities run the risk of crossing the limits of appropriateness, they are removed to the back area, a more private sphere. This appears to be the case with glossolalia, for instance.

Glossolalia is rarely practiced in middle class churches and if so, then only quietly. It is difficult - if not almost impossible - to observe middle class Pentecostals speaking loudly in tongues. Again, the social acceptability of the activity plays a role. Some middle class interviewees mention that it may be perceived as strange by new visitors if people spoke loudly in tongues during the church service. ${ }^{62}$ Yet, middle class Pentecostals believe in the gifts of the Spirit and in particular in the gift of tongues. Interestingly, the majority of my middle class informants mentioned that they had experienced the gift of tongues.

The affinity for glossolalia appears to be as prevalent among middle class Pentecostals as among other Pentecostals. Nevertheless, middle class Pentecostals abstain from speaking loudly in tongues during the church service. Those who speak in tongues during the church service mentioned that they do so very quietly and speak more loudly in tongues when they pray at home. Others abstain directly from speaking in tongues during services and reserve this practice for the private sphere. Camila, for instance, prefers to speak loudly in tongues at home but not in the congregation.

(...) speaking in tongues (...) is more of a personal thing with God than something to display in public. Yes, I believe that people can speak in tongues when you are worshipping, when you are in intimate prayer with 
God, that the Spirit can move you to say different things. But that is something between you and God, not a circus act. (...) I like to talk to God when I'm in the shower, when I'm drinking mate, when I get angry.

INTERVIEW CAMILA

The affinity that many middle class Pentecostals have for glossolalia is not expressed in the congregational practice of Pentecostalism. There is a difference between the religious tendencies of middle class Pentecostals and the style of their public religious practice. Middle class Pentecostals face the need to suppress their tendencies in order to create a legitimate and appropriate practice of Pentecostalism in the public sphere. They create a Goffmanian front region from which they ban the inappropriate practices. ${ }^{63}$ Middle class Pentecostals separate the private sphere from this front region - the public sphere of the church service. ${ }^{64}$

More private contexts separate from the church service appear to form a kind of back region where "the performer can relax: he can drop his front, forgo speaking his lines and step out of character." (Goffman 1959: 112) Socially unadapted practices are realized in the private sphere, the back region.

Besides the congregation, particularly pastors and obreros are responsible for the impression management. They act as directors of the "performance" by controlling the scene in the front region. In the case of violations against the principles of appropriate conduct, pastors or obreros reprimand the individual in question. Thus, in cases of strong spiritual manifestations, manifesting participants are taken out and brought to a more intimate back space within the church. ${ }^{65}$ Pastors and members strive to maintain a certain image during the church service, whereas the private sphere becomes a space for more intense Pentecostal practices.

63 See Goffman 1959. Goffman writes: "If an individual is to give expression to ideal standards during his performance, then he will have to forgo or conceal action which is inconsistent with these standards. When this inappropriate conduct is itself satisfying in some way, as is often the case, then one commonly finds it indulged in secretly (...)." (Goffman 1959: 41).

64 Lahire, in contrast, distinguishes between "marchés francs" and "marchés tendu" : "Les marchés tendus imposent de la mise en forme, de la preparation, du calcul, de l'attention, du soin, du souci, etc." (Lahire 2004/2006 : 632). He supposes that the difference between lower and higher social classes is that the latter are more frequently involved in the "marchés tendus". See Lahire 2004/2006: 632.

65 Individuals who cross the limits of appropriate behavior - by speaking loudly in tongues for instance - may be sanctioned as the example of the pastor from AC illustrates who approaches participants that speak in tongues. 


\subsubsection{Towards a de-Pentecostalized Style of Pentecostalism}

Analyzing the style of middle class congregations, one may question if this style is still Pentecostal. In fact, the style of middle class churches appears to be significantly less Pentecostal than the typical model one has in mind when thinking about Latin American Pentecostalism. Some of the characteristics that are often associated with Pentecostalism, such as the expressivity, emotionality, festivity, and the presence and practice of the gifts of the Holy Spirit are absent or only weakly developed. There appears to be a de-Pentecostalization of middle class Pentecostalism. When concerning the style of middle class church services, one may perhaps presume that middle class Pentecostals reject the typical Pentecostal beliefs in the gifts of the Holy Spirit. Nevertheless, this is not the case. As was discussed above, middle class Pentecostals believe in the gifts of the Holy Spirit, demons, exorcisms, and faith healing.

Yet, these beliefs become - if at all - only marginally visible in the religious practices during church services. Instead, middle class churches seek to ban spiritual practices from the church service. There is a difference between the beliefs and the public practices of middle class Pentecostals. Despite professing Pentecostal beliefs they abstain from fully practicing them. Rephrasing Grace Davie's popular "believing without belonging", one could describe the attitude of middle class Pentecostals as a "believing without public practice". 66 The reason for this appears to be their attachment to the middle class representations. Their attachment to middle class representations of the appropriate leads them to draw boundaries in opposition to their popular religious roots and to abstain from "inappropriate" Pentecostal practices. In consequence, the public practice of Pentecostalism constitutes a compromise between popular religion (Pentecostalism) and middle class representations, converting Pentecostalism into a more appropriate - and less Pentecostal - religious practice. ${ }^{67}$

66 See Davie 1994.

67 The religious taste of middle class Pentecostals indeed rejects many of the characteristics of popular religion, particularly the expressivity and focus on life improvement. Nevertheless, there still seems to be a strong link between the middle class taste and popular religion. The relationship of the middle class to popular religion is ambivalent: while they tend to reject many of the expressions of popular religion in the context of the church service, they do not neglect them in their beliefs and private religious practice. First, middle class Pentecostals remain attached to the holistic worldview since they believe in supernatural intervention, spiritual gifts and demonic possessions. Second, they believe in and seek miracles and some of them speak in tongues or even conduct exorcisms in their private sphere. Hence, rather than a total rejection of popular religiosity, they exhibit a taste that splits their religious practice into a non-popular public practice of religion and a private practice of religion which can assume popular elements. 
The "inappropriate" aspects of Pentecostalism to which middle class Pentecostals remain attached are transferred to the private sphere. Their Pentecostal identity becomes partly privatized. The private sphere constitutes an intimate sphere which protects middle class Pentecostals from the threatening glances of class peers. In private they are not at risk of being embarrassed and losing face. Therefore, the private sphere provides a space to break away from the social conventions of the middle class and the pressure to behave appropriately. Here, middle class Pentecostals can dedicate themselves - without feeling compromised - to what is regarded elsewhere as "inappropriate". Yet, it is hard to know to what extent middle class Pentecostals engage in the "inappropriate" aspects of Pentecostalism in their private sphere. Even though there is some evidence for the presence of stronger Pentecostal practices in the private sphere of middle class Pentecostals - several interviewees stated that they dedicate themselves to stronger spiritual practices, such as speaking in tongues, in private - it is difficult to estimate to what degree they relax from the middle class representations in the private sphere. In order to study this question, a comprehensive study in its own right would be necessary.

In sum, the differentiation between public and private practice can be interpreted as a strategy of middle Pentecostals to solve the conflict between their attachment to popular religion and the representations of the educated middle class. The more visible public practice adapts to the representations of appropriateness, whereas the private sphere is the arena in which middle class Pentecostals permit the "inappropriate" aspects of their religiosity to take effect. More intense Pentecostal practices preferably take place in the private sphere.

\subsection{Authenticity, Respectfulness and Selflessness: Moral Boundaries}

Analogous to the results from Lamont's study about the U.s. American and French upper middle class, ${ }^{68}$ Argentinean middle class Pentecostals draw moral boundaries. Moral boundaries are boundaries that refer to the morality of actors. Creating moral boundaries means attributing specific moral qualities to oneself and different moral qualities to the other from whom one seeks distinction. ${ }^{69}$ Middle class Pentecostals emphasize a range of moral values such as authenticity, honesty, respectfulness, selflessness, freedom, and autonomy. By stressing these values they insinuate, directly or indirectly, that other Pentecostals often lack these qualities.

68 See Lamont 1992.

69 See Lamont 1992: 4. 
Remarkably, when drawing moral boundaries, middle class Pentecostals do not refer to the ascetic lifestyle which is often seen as a characteristic of Pentecostalism. As was suggested by different scholars, middle class Pentecostals are less strict in their lifestyle and withdraw from the puritan moral rules, that included, among other characteristics, a strong control of the physical appearance. ${ }^{70}$ Even though Argentinean middle class Pentecostals are committed to a less ascetic and rather worldly lifestyle which may embrace fashionable clothing, football, and even alcohol consumption, they do not depreciate the ascetic lifestyle of other Pentecostals. This may be due to the fact that a highly ascetic Pentecostalism is not very visible in Buenos Aires. The majority of medium-sized and larger churches in Buenos Aires do not impose draconian moral rules on their members. Therefore, a less ascetic lifestyle is not a unique characteristic of middle class congregations but of many Pentecostal churches in and around Buenos Aires. Instead of asceticism, other moral values appear to be more suitable for the boundary work of middle class Pentecostals. Four types of values that are often mentioned by middle class Pentecostals are: freedom and autonomy, authenticity, selflessness, and respectfulness. Each of these values will be discussed separately in the following subsections.

\subsubsection{Freedom and Autonomy}

Freedom and autonomy are essential values in most modern societies, where they tend to be particularly upheld by the educated middle class. Therefore, it is not surprising that these values are also strongly emphasized by middle class Pentecostals. They portray themselves as independent actors who refuse to be externally controlled by other actors. By underlining their autonomy, they draw a boundary in opposition to the public imaginary of Pentecostalism as a religion of strong leaders and obedient followers. Their desire for autonomy becomes particularly evident with regard to church leadership. Middle class interviewees prefer to have a leader who grants them liberties within and outside the church. They regard themselves as responsible actors who should decide for themselves. An authoritarian church leader who limits their freedom is not appreciated. Sara, for instance, argues that leaders should not control the behavior of church members.

What bothers me, personally, is that the leaders tell people what they have to do, I don't like that; telling them what to do doesn't seem right to me.

70 See Lindhardt 2012: 100-101, Martin 1995: 108, 116; Robbins 2004: 121-122. 
Instead of teaching them through the Word, they just give them rules and stuff like that.

INTERVIEW SARA

The quote from the interview with Sara illustrates the importance of a certain degree of liberty within the church. According to many interviewees, congregations should promote individual autonomy and self-realization. An excessively authoritative leadership is not perceived as contributing to this requirement. Thus, strong hierarchies within the church and a centralist leadership are regarded critically. Eduardo, for instance, argues that Pentecostals focus too much on the figure of the pastor who becomes often an almost absolutist leader. Instead of a centralist leadership, he prefers a more democratic leadership. ${ }^{71}$

In analogy to their disapproval of authoritative leadership, middle class Pentecostals are not receptive to an authoritarian style of preaching. An authoritarian style of preaching is experienced as aggressive and potentially manipulative. Fabian, for instance, argues that pastors should not speak in a challenging, but instead in a normal voice. ${ }^{72}$

Moreover, many respondents explained that they dislike the constant use of repetition practices. ${ }^{73}$ In many Pentecostal churches services these practices are ubiquitous. Preachers tend to frequently ask the audience to repeat phrases and/or to act out specific movements. A popular type of repetition practice, for instance, is the rhetorical question "Cuantos dicen Gloria a Dios?" ("How many of you say > glory to God $<$ ?") to which the audience is expected to respond "Gloria a Dios!" ("Glory to God!"). Other repetition practices in church services can involve physical movements: standing up and stomping the ground three times and repeating a phrase or laying hands on one's own head and withdrawing them rapidly while shouting "Fuera!" These practices imply a spiritual cleansing of malicious forces. But there are also simpler practices such as raising or waving one's arm and repeating a phrase. These practices are instructed by the preacher and are often described as strategies to integrate the audience more actively into the church service.

71 Interview Eduardo.

72 Interview Fabian.

73 Also middle class pastors tend to stress freedom of expression and state that they do not want to control the expressions of their members. Pastor Oscar, for instance, describes his church Iglesia del Libertador in contrast to lower class Pentecostal churches as a church where participants can express themselves freely (Interview Pastor Oscar). 
Practices of repetition are almost totally absent in middle class congregations. Only a few middle class pastors apply repetition practices and when doing so, they rarely employ them. Middle class interviewees depict these practices as silly and manipulative. Particularly a video from a church service of Juan Crudo who asks the audience to conduct different repetitions practices such as waving their arms, repeating a phrase, and blowing a kiss to God stimulated critical statements about repetition practices. The following quote from an interview with Emilia illustrates her aversion to repetition practices.

(...) well, I don't like those things. Like greeting with your arm. I don't like it when they 'tele-direct' us, like when they tell us from the pulpit, 'Raise your hands, lower your hands.' I get annoyed when they start with 'Raise your hand, lower your hand, say this or say that.' One greeting is enough to establish a friendly environment, but they get too controlling and I get annoyed.

INTERVIEW EMILIA

Repetition practices are perceived as encroaching upon participants' freedom of expression. Again, the autonomy of the individual is emphasized. Middle class Pentecostals do not want to feel controlled in their expressions during the service. Instead, they claim that the expressions and practices of the participants should be intrinsically motivated. Marta, for instance, asserts that repetition practices force participants to carry out activities they do not really want to perform.

Well, all the silly things they make you do, 'Shake hands, brother,' because, I mean, they are things that motivate you, but they make you to do an absurd amount of rituals that maybe you don't want to do. They need to stop doing this, in my opinion. We need more free personal expression, not to be told, 'Ok, now hold holds, raise your hands.' Maybe that is the last thing you actually want to do. And everyone does it, because the pastor tells us to.

INTERVIEW MARTA PART 2

Repetition practices are rejected as a practice that undermines the autonomy and liberty of actors.

Ironically, middle class Pentecostals emphasize the ideal of free expression, but at the same time exercise strong control over their expressions by setting limits for appropriate religious practice, as described above. This contradiction appears to be resolved by the difference between external and internal control. 
Controlling oneself is perceived differently from being controlled by the pastor. Hence, behaving appropriately during the church service is not necessarily experienced as the product of external control but as an internal control.

The views on autonomy also indicate the value which middle class interviewees attribute to the authenticity of their behavior. They do not want to perform practices and display expressions of religious devotion that they do not feel. Instead, they expect themselves and others to be authentic in their expressions.

\subsubsection{Authenticity}

Authenticity is a ubiquitous topic. Authenticity is not only related to the physical expressions and practices of devotees, but also the content of the sermon. When evaluating the quality of a sermon, interviewees refer to the correctness of its doctrines. Particularly the concept of sana doctrina was mentioned again and again in the interviews. The idea of sana doctrina refers to the basic truths that are expected to be applied in every area of congregational practice. With regard to the sermon sana doctrina refers to the Biblical basis and the authenticity of the Bible interpretation which is conceived as crucial as Pablo puts it: "La doctrina es lo principal" ("The doctrine is the most important thing"). ${ }^{74}$ The following insights from the interviews provide some indications as to the meaning of sana doctrina.

Isabela states that she would leave her church if she noticed any deviations from the sana doctrina. In order to verify the match between the sermon and the sana doctrina, she recommends comparing the content of the sermon with that of the Bible in case of doubt. ${ }^{75} \mathrm{~A}$ strong Biblical basis is also an essential element for Luis, who states that he likes his congregations because its pastors provide clear and precise sermons that are based on the Bible.

Preaching is Biblical. What do I mean by 'Biblical'? That it is read from the Bible, very precisely and clearly from the Word of God. It does not mean going to the pulpit and talking about any topic and not basing it on the Bible. In this case, here we preach the Word of God, the very words of God. They aren't so much thematic sermons, on one topic or another. They are Biblical readings. The Bible is preached directly. But in other places, the preachers talk about some topic for 50 minutes and the Bible for only 5 minutes.

INTERVIEW LUIS

$74 \quad$ Interview Pablo Part 1.

75 Isabela Part 1. 
Luis describes the focus on the Bible as the principle element of a good sermon. According to him, good sermons primarily explicate the Bible, whereas poor sermons would be dedicated for the most part to other issues. ${ }^{76}$ According to middle class Pentecostals, the sermon should consist of an authentic representation of the word of God. Miguel summarizes the concept of sana doctrina in simple terms: "Palabra de Dios $100 \%$, eso es lo importante" (" $100 \%$ word of God that is the important thing") ${ }^{77}$ With the concept of sana doctrina, middle class Pentecostals seek to establish a distinction between what they perceive as the real gospel and a corrupted gospel which is based on incorrect Bible interpretations and/or manipulations. Following this concept, only a Bible teaching that is based completely on the Bible is an authentic Bible teaching.

Again, education plays an important role. The ability of a pastor to provide an authentic presentation of the Bible is attributed to the pastor's theological education. Sara, for instance, argue that pastors who do not preach the sana doctrina lack theological training. ${ }^{78}$ Theological training constitutes an important indicator for the quality of preaching and its reliability concerning the Biblical foundation. Educated pastors are seen as preaching in an authentic way, whereas untrained pastors lack this ability. This differentiation evidently draws deep boundaries in opposition to other Pentecostal congregations that do not have well trained pastors and are therefore thought to deliver instead of the sana doctrina a corrupted teaching of the Bible. Many of the Pentecostal congregations in the conurbano are perceived as moving beyond the sana doctrina in their teaching and practices and are consequently not regarded as being real Christians.

The value of authenticity concerning the sermon becomes particularly evident in the concept of sana doctrina. However, the sermon is not the only area of the church service where the value of authenticity plays an important role. Middle class Pentecostals stress the value of authenticity also with regard to spiritual practices. Strong spiritual practices which one can observe in some Pentecostal churches are conceived of as an inauthentic, theatrical show or even as an expression of mental illness. Several middle class interviewees describe exorcisms as a form of religious show and the individuals involved as acting in a psychologically deviant manner. Carlos, for instance, believes in

${ }_{7} 6$ Another indication is provided by Viviana, who likes the fact that her congregation keeps itself to the doctrine. This means for her that the congregation does not preach contents that are not in the Bible (Interview Viviana).

77 Interview Miguel Part 2.

78 Interview Sara. Also Carlos clarifies that the sana doctrina depends on the theological training of the preacher (Interview Carlos). 
exorcisms. He himself works in the church's ministry of spiritual liberation. Nevertheless, he reports that there is a lot of imagination involved in liberation. According to Carlos, only a very small minority of the individuals that appear to be possessed are really possessed. ${ }^{79}$ For the vast majority of cases he regards mental health problems as the reason for manifestations. He is not the only interviewee that expresses doubts about the manifestations and exorcisms. Although all middle class interviewees believe in the existence of demonic possessions and claim that there is a need for exorcisms, many of them share Carlo's position and put the authenticity of demonic manifestations into doubt. Frequently, strong spiritual manifestations are described as a theatrical show in which the manifesting individuals act. Moreover, supposed manifestations of demonic possessions are portrayed as hysterical reactions in a context which encourages such mental conditions. Isabela, watching a video of a GIL exorcism, describes the dynamic in GIL as collective hysteria. It goes without saying that she dislikes such a dynamic. ${ }^{80}$ Also Camila has strong feelings about spiritual manifestations during church services. Her criticism is that instead of emphasizing Jesus, pastors encourage people with psychological problems to play act and to commit estupidéces (stupidities). ${ }^{81}$ Hence, the general suspicion among middle class Pentecostals is that the mechanism behind spiritual manifestations in church services are psychological problems or theatrics in which the congregation engages.

Questioning the authenticity of other Pentecostals involves not only questioning their moral qualities but also their religious authority. The faith of the other appears less legitimate due to a lack of authenticity. In contrast to the inauthentic other, middle class Pentecostals describe themselves as authentic believers.

\subsubsection{A Selfless Faith}

The attitude of middle class Pentecostals towards many of the characteristics of other Pentecostals is often marked by skepticism. This attitude becomes evident not only with regard to the music, atmosphere, and expressions of lower class Pentecostals but also the supposed motivations for their religious activity. Criticism is raised against a style of Pentecostalism which emphasizes miracles and the healing from suffering. Some of the middle class interviewees infer that most Pentecostals only seek miracles but do not care about God. The following quote from an interview with Maria summarizes this idea:

79 Interview Carlos.

$80 \quad$ Interview Isabela Part 2.

81 Interview Camila. 
(...) what the Pentecostal churches - especially poorer churches - are looking for is the spiritual touch, miracles, healing. They are not looking for God himself, as much as they claim to be.

INTERVIEW MARIA PART 2

Lower class Pentecostals are portrayed as pragmatic, egoistic actors who seek an improvement in their life by performing magical practices. This type of spiritual pragmatism is disdained by middle class respondents. By contrast, they tend to depict God as the objective and motive of their religious activity. Middle class Pentecostals prefer to conceive of religious practice as a selfless activity dedicated to God. They appear to follow the ideal of a "disinterested" faith in which the main interest is the supernatural and not its powers and the empirical advantages which the faithful devotee can derive from it.

Middle class Pentecostals prefer to portray themselves as practicing religion as an end in itself. At the same time, it is not clear to what extent middle class devotees actually act as disinterested, selfless religious actors. Also, middle class Pentecostals seek miracles and supernatural support in order to cope with their daily reality. They may, however, depict their search for a miracle as a secondary objective and present themselves as primarily seeking God. ${ }^{82}$

The ambivalent relationship which middle class Pentecostals have concerning divine miracles also becomes evident in their attitude towards prosperity gospel. Asking middle class Pentecostals about the teologia de la prosperidad (prosperity gospel), they usually react with tough criticism. The disapproval of prosperity gospel becomes particularly evident when interviewees watch videos from the sermons of Juan Crudo, a famous representative of prosperity gospel in Buenos Aires. His prosperity sermons are described as selling fast and magical solutions to the audience. Moreover, interviewees suppose that prosperity preachers create false expectations that can drive believers to frustration if the expected miracles do not happen. For example, Claudia perceives Juan Crudo's sermon as offering "McDonalds-like" solutions to a lower class audience. $^{83}$

82 Miracles are not neglected. They are perceived as a potential outcome of the religious activity. However, this outcome should not form the central motivation for the religious activity, according to middle class interviewees. Finally, there is also salvation as a potential objective of religious activity which is not a selfless objective.

83 Interview Claudia Part 2. Maria also describes Crudo's sermon as transmitting the idea of a magical God who realizes the dreams of every faithful devotee. She perceives Pastor Crudo to be selling dreams to his audience (Interview Maria Part 2). 
Middle class Pentecostals tend to reject the idea of a direct transaction between God and the devotee which assumes that devotees will be repaid by God according to their "investments". At the same time, the possibility of prosperity in this world is not denied. God and the evangelical lifestyle may help devotees to prosper. ${ }^{84}$ Middle class Pentecostals usually accept the general notion that God may reward followers in different areas of their daily lives. At the same time, they disapprove of a focus on prosperity.

Accordingly, there normally are no direct references to prosperity gospel in the sermons of middle class pastors. In fact, all the middle class pastors I interviewed strongly reject prosperity gospel. Nevertheless, some preachers occasionally refer to the general idea that God rewards devotees for their efforts.

Moreover, middle class Pentecostals associate prosperity gospel with an emphasis on offerings. The importance that some Pentecostal churches place on the financial contributions of their members is therefore rejected. Middle class congregations abstain from emphasizing financial sacrifices and endeavor to separate financial donations from spirituality. ${ }^{85}$

Nevertheless, members of middle class churches are also called on to make sacrifices. But instead of financial sacrifices, middle class congregations rather demand sacrifices of time and energy from their members. Members are encouraged to create their own ministries within the church and engage in activities for the good of the community and society.

The middle class congregation Iglesia del Libertador, for instance, strongly encourages its members to dedicate themselves actively to a task within the community. Only those who render a service to the congregation and/ or society are considered to be active members of the church. Those who instead participate in church services, church groups and tithe are only regarded as participating members, but not as active members. ${ }^{86}$

Hence, the ideal of selflessness becomes also manifest in the form of efforts to improve society. Middle class churches show a pronounced sense of mission vis-à-vis the society. Creating a positive impact on society is also an objective that middle class pastors tend to stress. For instance, Pastor David from the

84 Interview Pastor Oscar Part 2; Interview Pastor Alejandro.

85 Emphasizing offerings and tithing is perceived as a central element of the prosperity gospel. When I asked Pastor Manuel from the middle class church Comunidad Cristiana about the church's stance on the prosperity gospel, he directly answered that his church would not emphasize offerings (Interview Pastor Manuel).

86 Interview Pastor Oscar Part 1. 
middle class church Iglesia La Puerta Abierta points to the social role of Pentecostals and emphasizes the importance of social aid projects in society. ${ }^{87}$ The attitude concerning social aid is also illustrated by a sermon from Iglesia del Libertador. In this sermon the preacher criticizes another Pentecostal church for being excessively spiritual and disregarding the area of social aid. The other church is described as lacking religious development. The faith of this congregation is conceived of as magical and therefore immature. Iglesia del Libertador, in contrast, is described as a congregation with a developed religious faith that emphasizes serving the other. According to the discourse of the preacher, giving and helping the other are central features of religious development. For this reason, providing social aid is conceptualized as an expression of religious maturity. ${ }^{88}$ Similarly, also middle class respondents claim that churches should include ministries of social help. They argue that churches should be engaged in society and deliver social assistance to the most vulnerable segments of the society. They regard it as part of their mission to assume responsibility and to be engaged in society. Particularly the poor are a frequent target of attempts to improve society. Social projects that supply the poor with food and clothing or professional counseling are common social services one can observe in middle class churches. These services allow middle class Pentecostals not only to portray themselves as morally respectable actors but also to illustrate their social position and to draw a boundary between those who can give and those who receive. Moreover, social projects lead to public recognition and help to accumulate legitimacy, as already described above.

The concept of selflessness draws a strong moral boundary between those who are described as selfish actors that only seek an improvement of their life and the selfless (middle class) Christians that practice Pentecostalism due to their devotion to God and seek to improve the life of others.

\subsubsection{Being a Respectful Devotee}

Not only the importance of miracles, but also the way in which miracles are sought is a controversial topic for middle class Pentecostals. Other Pentecostals are suspected of not complying with the norms for appropriate, respectful behavior when they seek miracles. According to middle class interviewees, devotees should interact in a respectful way with God: they should subordinate themselves to God and respect God's sovereignty. Other Pentecostals are suspected of placing themselves in a position superior to God by seeking to control God's actions in order to carry out divine miracles. The value of

$87 \quad$ Interview Pastor David.

88 Iglesia del Libertador, 12th June 2011. 
respectfulness becomes particularly manifest with regard to prayers and faith healing practices.

In middle class churches, the style of prayers tends to be calmer and more cautious than in many other Pentecostal churches. At some instants the voice may be raised, but the general tone of the prayer is quiet and contemplative. The prayer is usually accompanied by a piano playing softly in the background. The audience remains silent during the prayer. Participants may sit or stand in their places and incline their heads while they contemplate the words of the praying individual, some raise a hand and speak in a quiet voice. Prayers often start with thanking God for his/her greatness and support; after this they may apologize for the shortcomings of the congregation and finally present some requests to God. They can ask for specific concerns like the health of a particular member or more generally for support and peace.

Strong, demanding prayers are not only widely absent in the middle class congregations that I studied, they are also criticized by middle class interviewees. In many other Pentecostal churches, faith healing and the search for miracles are often accompanied by strong prayers which request God for healing. In these prayers pastors may emphatically ask God for specific interventions. This style of prayer is depreciated by middle class respondents. Watching a video of a prayer in a Pentecostal church of the conurbano in which the preacher prays for the creation of gold and silver dental fillings, Horacio describes the style of the prayer as too demanding. In his view, the pastor tries to force God to perform miracles. He dislikes this type of religious practice and argues that the pastor should encourage the audience to worship God instead of seeking to bring about miracles. ${ }^{89}$ Maria presents a similar opinion. She believes that God can create and improve dental fillings. But she dislikes the style in which the prayer is conducted.

(...) I don't like it, I don't like it. It's like he's trying to control the hand of God, (...) I think God can fix things, make changes, but I don't like how [the pastor] leads. It's almost like he's saying, "Now God do this, now put your hand there," and then all the screaming. (...) I don't like it, it's almost like he's steering the hand of God.

INTERVIEW MARIA PART 2

It appears to Maria as if the preacher is trying to control the hand of God. Pastors shouting and aggressively demanding God to perform miracles are regarded as lacking humility. Middle class Pentecostals perceive intense

89 Interview Horacio. 
prayers as the attempt to violently force God to intervene in a specific way: these prayers seek to invert the natural hierarchy between the supernatural and the devotee. According to middle class interviewees, devotees can request God's support but not with force. Therefore, prayers are preferred to be carried out in a calm voice that appears less "aggressive".

Some middle class interviewees stipulate that Pentecostals tend to believe in a mechanism for receiving miracles. They disapprove of this idea and argue that there is neither a method to produce supernatural miracles nor a way to persuade God to intervene in a specific manner in daily life. According to them, God would instead intervene whenever God wants. Although they reject the idea of a manipulable supernatural, they believe that there are modes of conduct that may provide a positive context for supernatural interventions. However, a guaranty for divine miracles does not exist. Luis explains that there is no general method for healing people.

(...) there's no one way to heal. All miracles come from God. He conducts them how, when, and where he wants. All I can do is take on an attitude of faith in miracles, that God does them. What can I do? Have fatih, live a holy life, be a perfect temple for God to do his work. But living a good and holy life doesn't make God perform miracles. God will perform miracles when He wants to. There's no method, no system.

INTERVIEW LUIS

According to Luis, God would heal whenever God wants: a faithful lifestyle would not necessarily produce miracles. Yet, he also supposes that exhibiting an actitud de fe - a faithful lifestyle - creates a conducive context for the occurrence of divine miracles.

Pentecostal practices that endeavor to heal suffering individuals immediately from their afflictions are seen as "acts of omnipotence": the human being seeks to intervene in the supernatural and to control God. ${ }^{90}$ Faithful devotees are instead expected to be humble actors vis-a-vis God: they may ask for favors, but they must do this in a respectful manner which underlines the sovereignty of God and the subordinate position of the individual. Other Pentecostals are considered as lacking an understanding of their position and being unable to develop appropriate, respectful forms to deal with the supernatural.

In sum, an appearance of moral correctness seems to constitute a key factor for earning respect among educated middle class Pentecostals. Skeggs writes

9o See, for instance, Interview Emilia. 
with regard to the drawing of moral boundaries and the display of one's morality:

The ethical self (...) becomes an imperative: it has to be displayed as a sign of one's social responsibility, self-governance, morality and value.

SKEGGS 2005: 974

According to Skeggs, the ethical self is conceptualized as standing in opposition to the "bad selves" of those who "cannot operate an ethical self". ${ }^{91}$ These "bad selves" are, of course, the "inappropriate selves" of the lower class. ${ }^{92}$ The imaginary of the "inappropriate other" and the efforts to institutionalize the boundaries vis-à-vis these "bad selves" will be addressed in the following chapter.

\subsection{Summary}

This chapter described the boundary work of middle class Pentecostals. Middle class Pentecostals tend to draw five types of symbolic boundaries: legitimate, structural and organizational, educational, expressive, and moral boundaries. These boundaries become manifest in the religious tastes and styles that middle class Pentecostals display.

Middle class Pentecostals draw legitimate boundaries by creating a formal circle of Pentecostalism. Belonging to the formal circle depends on different requirements: membership in official evangelical umbrella organizations, enrollment in the Registro Nacional de Culto, participation in the Consejo de pastores, the educational involvement of pastors in Bible institutes, and possibly the engagement in an evangelical newspaper. These characteristics contribute to the formal recognition of a church and increase its legitimacy. While the majority of Pentecostal churches in Argentina do not fulfill these requirements, middle class churches are usually deeply embedded in the formal circle and some of its pastors even control the bodies of the formal circle of Pentecostalism. Embodying and controlling legitimacy, middle class Pentecostals are not only able to distinguish themselves from other Pentecostal congregations as more legitimate religious organizations, but can even de-legitimize other Pentecostals by excluding them from the formal circle of Pentecostalism.

Structural and organizational boundaries refer to churches' physical structure and organization. Middle class Pentecostals want their churches to

\footnotetext{
91 Skeggs 2005: 974.

92 See Skeggs 2004: 79-118.
} 
represent order, tidiness, and excellence. Therefore, middle class churches tend to have a tidy appearance, well managed facilities, sophisticated equipment, well-structured church services with high quality music, and a variety of secular services. The secular services of middle class churches are often related to the educational aspirations of its middle class membership.

Further, middle class Pentecostals place a strong emphasis on education. The drawing of educational boundaries not only becomes visible in the extensive educational programs of middle class churches but also in the way sermons are preached. Sermons are often preached in a rather academic way and frequently address topics of personal growth and moral improvement. Moreover, pastors are evaluated by middle class Pentecostals on the basis of their educational achievements. Lower class pastors are regarded skeptically since they lack, according to middle class Pentecostals, the educational means to teach and implement an appropriate form of Pentecostalism. Hence, education becomes an essential asset for drawing boundaries in opposition to the "uneducated" Pentecostals of the lower class neighborhoods.

Another central type of boundary drawing takes place in the context of the church service in the form of expressive boundaries. Expressive boundaries refer to the visible performances of participants and pastors during church services. While Pentecostalism is notorious for its highly expressive and emotional style and its spiritual practices, middle class Pentecostals abstain from displaying these attributes. Church services in middle class congregations tend to be less expressive and emotional and more sober. Spiritual practices such as faith healing and speaking in tongues are barely visible. Inappropriate manifestations of Pentecostalism are eliminated from the public sphere of the church service. While the service is dedicated to a more appropriate performance of Pentecostalism, inappropriate Pentecostal tendencies can become manifest in the private sphere, in a back region hidden from the glances of middle class peers.

Finally, middle class Pentecostals also draw moral boundaries between themselves and other Pentecostals. They tend to portray themselves as more authentic, selfless, and respectful than other Pentecostals who are not only suspected of practicing Pentecostalism in an inauthentic way but of doing so for selfish reasons and lacking respectfulness and humility when addressing God.

In total, the drawing of these five types of boundaries goes along with more "appropriate" tastes and styles of Pentecostalism. A new type of Pentecostalism emerges which fits better with the representations of the middle class. Drawing symbolic boundaries in opposition to the "inappropriate" attributes of Pentecostalism, middle class Pentecostals can negotiate the appropriateness 
of their religious belonging. They reduce tensions with their class representations and create a socially more acceptable form of Pentecostalism.

Some of these boundaries correspond to oberservations made by other scholars. Miller and Yamamori studying the social engagement of Pentecostals contend that particularly middle class congregations develop social help programs. ${ }^{93}$ Other scholars exploring single cases of middle class churches have found that these churches show a lower level of expressivity and are less inclined towards spiritual warfare. ${ }^{94}$ However, the results of this study diverge from the supposed tendency of middle class Pentecostals towards prosperity gospel. ${ }^{95}$ At least for the case of middle class Pentecostals in Argentina, there appears to be no such tendency: the interviewed pastors and lay members reject the health and wealth gospel.

93 Miller and Yamamori 2007: 3,127,213.

94 See Hasu 2012, B. Martin 1995: 108, 116. Also Nathalie Luca (1999b: 107; 2000: 535) observes in the Yoido Full Gospel Church in Seoul (South Korea) that university students organize their own church services. These services are shaped by a different religious style which is less emotional and involves to a minor degree the charismatic gifts.

Droogers 2000: 47. 